NASA/TM-2005-213562

\title{
Preliminary Investigation of Ice Shape Sensitivity to Parameter Variations
}

Dean R. Miller and Mark G. Potapczuk

Glenn Research Center, Cleveland, Ohio

Tammy J. Langhals

QSS Group, Inc., Cleveland, Ohio 
Since its founding, NASA has been dedicated to the advancement of aeronautics and space science. The NASA Scientific and Technical Information (STI) Program Office plays a key part in helping NASA maintain this important role.

The NASA STI Program Office is operated by Langley Research Center, the Lead Center for NASA's scientific and technical information. The NASA STI Program Office provides access to the NASA STI Database, the largest collection of aeronautical and space science STI in the world. The Program Office is also NASA's institutional mechanism for disseminating the results of its research and development activities. These results are published by NASA in the NASA STI Report Series, which includes the following report types:

- $\quad$ TECHNICAL PUBLICATION. Reports of completed research or a major significant phase of research that present the results of NASA programs and include extensive data or theoretical analysis. Includes compilations of significant scientific and technical data and information deemed to be of continuing reference value. NASA's counterpart of peerreviewed formal professional papers but has less stringent limitations on manuscript length and extent of graphic presentations.

- TECHNICAL MEMORANDUM. Scientific and technical findings that are preliminary or of specialized interest, e.g., quick release reports, working papers, and bibliographies that contain minimal annotation. Does not contain extensive analysis.

- CONTRACTOR REPORT. Scientific and technical findings by NASA-sponsored contractors and grantees.
- CONFERENCE PUBLICATION. Collected papers from scientific and technical conferences, symposia, seminars, or other meetings sponsored or cosponsored by NASA.

- SPECIAL PUBLICATION. Scientific, technical, or historical information from NASA programs, projects, and missions, often concerned with subjects having substantial public interest.

- TECHNICAL TRANSLATION. Englishlanguage translations of foreign scientific and technical material pertinent to NASA's mission.

Specialized services that complement the STI Program Office's diverse offerings include creating custom thesauri, building customized databases, organizing and publishing research results ... even providing videos.

For more information about the NASA STI Program Office, see the following:

- Access the NASA STI Program Home Page at http://www.sti.nasa.gov

- E-mail your question via the Internet to help@sti.nasa.gov

- Fax your question to the NASA Access Help Desk at 301-621-0134

- Telephone the NASA Access Help Desk at 301-621-0390

- Write to:

NASA Access Help Desk

NASA Center for AeroSpace Information 7121 Standard Drive

Hanover, MD 21076 
NASA/TM-2005-213562

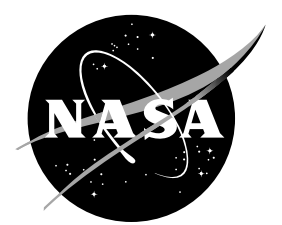

\section{Preliminary Investigation of Ice Shape Sensitivity to Parameter Variations}

Dean R. Miller and Mark G. Potapczuk

Glenn Research Center, Cleveland, Ohio

Tammy J. Langhals

QSS Group, Inc., Cleveland, Ohio

Prepared for the

43rd Aerospace Sciences Meeting and Exhibit

sponsored by the American Institute of Aeronautics and Astronautics

Reno, Nevada, January 10-13, 2005

National Aeronautics and

Space Administration

Glenn Research Center 


\section{Acknowledgments}

The authors would like to acknowledge the contributions of Robert Ide and John Oldenburg of NASA Glenn Research Center for their insight in the design of this experiment, and for their help in selecting the conditions used for this study. The authors would also like to recognize the contributions of the NASA Icing Research Tunnel staff for their technical support and operation of the icing tunnel in support of this investigation.

Available from

NASA Center for Aerospace Information 7121 Standard Drive

Hanover, MD 21076
National Technical Information Service 5285 Port Royal Road Springfield, VA 22100 


\title{
Preliminary Investigation of Ice Shape Sensitivity to Parameter Variations
}

\author{
Dean R. Miller and Mark G. Potapczuk \\ National Aeronautics and Space Administration \\ Glenn Research Center \\ Cleveland, Ohio 44135 \\ Tammy J. Langhals \\ QSS Group, Inc. \\ Cleveland, Ohio 44135
}

\begin{abstract}
A parameter sensitivity study was conducted at the NASA Glenn Research Center's Icing Research Tunnel (IRT) using a 36 inch chord $(0.91 \mathrm{~m})$ NACA-0012 airfoil. The objective of this preliminary work was to investigate the feasibility of using ice shape feature changes to define requirements for the simulation and measurement of SLD icing conditions. It was desired to identify the minimum change (threshold) in a parameter value, which yielded an observable change in the ice shape. Liquid Water Content (LWC), drop size distribution (MVD), and tunnel static temperature were varied about a nominal value, and the effects of these parameter changes on the resulting ice shapes were documented. The resulting differences in ice shapes were compared on the basis of qualitative and quantitative criteria (e.g. - mass, ice horn thickness, ice horn angle, icing limits, and iced area). This paper will provide a description of the experimental method, present selected experimental results, and conclude with an evaluation of these results, followed by a discussion of recommendations for future research.
\end{abstract}

$\begin{array}{ll}\text { AOA } & \text { angle of attack } \\ \text { IRT } & \text { Icing Research Tunnel } \\ L W C & \text { liquid water content } \\ M V D & \text { median volume diameter } \\ \text { SLD } & \text { super-cooled large droplets } \\ T_{t} & \text { total temperature } \\ T_{s} & \text { static temperature } \\ V & \text { airspeed } \\ \text { WBS } & \text { work breakdown structure }\end{array}$

\section{Nomenclature}

\section{Introduction}

How good does it have to be? That is a question which has been asked repeatedly of scientists and engineers developing new capabilities for simulation and measurement of SLD icing conditions. The recent emphasis by NASA and other international partners on extending the current capabilities of engineering tools (icing tunnels and tankers, ice accretion computer codes) to include Super-cooled Large Droplets (SLD) has once again focused renewed attention on this question.

NASA and it's international partners developed an SLD Technology Roadmap to guide the development of SLD Engineering Tools to support certification in SLD icing conditions. This SLD Technology Roadmap identified the key technology elements and supporting research investments needed to develop SLD engineering tools. ${ }^{1}$ The SLD Technology Roadmap was later translated into a project plan having a schedule and Work Breakdown Structure (WBS). ${ }^{2}$ 
During the initial stages of developing these technical plans, it was recognized that requirements were needed to define "how good" the SLD simulation capabilities needed to be. Therefore, a specific task was incorporated into the SLD Engineering Tool Development Project Plan to address this need (Task 1.1). ${ }^{2}$ The definition of requirements was intended to provide a "target" for SLD simulation in quantified terms. This served the dual purpose of providing guidance about: (1) what essential features or characteristics need to be simulated, and (2) how accurately these characteristics need to be simulated. It was anticipated that these requirements would be developed by means of sensitivity studies, either experimental or computational.

Two important areas of the project plan, where the definition of requirements would be very beneficial, are: (1) updating ice prediction codes to include SLD icing effects, and (2) development and assessment of icing cloud instrumentation to measure SLD icing conditions. Though work has been proceeding in these areas, it would be desirable to define limits for "how good" the SLD ice prediction capability, and SLD icing condition measurement need to be.

This paper will present the results of an experimental study whose objective was to investigate the feasibility of using changes in ice shape features as a potential method for defining requirements. The authors recognized that this was a difficult, complex issue to address. Therefore, this first investigation was limited to a very basic sensitivity study where changes in LWC, MVD, and temperature were assessed based on perceivable changes in ice shape.

This parameter sensitivity study was conducted at the NASA Glenn Research Center's Icing Research Tunnel (IRT) using a 36 inch chord $(0.91 \mathrm{~m})$ NACA-0012 airfoil. Liquid Water Content (LWC), drop size (MVD), and tunnel static temperature were varied about a nominal value, and the effects of the parameter change on ice shape were noted. The experimental method, test setup and test conditions will be described first. Then selected ice tracings will be presented and compared on the basis of qualitative and quantitative factors. The report will conclude with an assessment of the test method, significance of the results, and recommendations for future research.

\section{Experimental Methodology}

\section{A. Approach}

The objective of this experimental sensitivity study was to investigate the feasibility of using changes in ice shape features as a means of developing requirements for improvements to SLD ice prediction codes, and the instrumentation used to measure SLD icing conditions. It was also desired to assess the practicality of implementing such a method, and to document the relative level of ice feature changes corresponding to the LWC, MVD, and temperature changes selected for this study.

Since this was recognized to be a non-trivial task, this sensitivity study was planned to be the first in a sequence of experimental investigations. The plan was to use an icing wind tunnel to vary LWC, MVD, and temperature conditions about a nominal condition, document changes in the resultant ice shapes, and in some manner use these changes as a metric for developing accuracy estimates. Ultimately, we would like to identify the minimum change in a parameter (threshold) which produces an observable change in the resulting ice shape. This "threshold" value could then be used to develop an estimate of the required accuracy for that parameter.

Our plan was to keep this first test simple in scope, by choosing an icing spray condition having a nominal LWC, MVD, and temperature. We were not certain about what the "threshold" value would be for LWC, MVD, and temperature. Therefore, we used our judgment to select changes in LWC, MVD, and temperature which would yield an observable change in the resulting ice shapes. This was done with the assumption that the actual "threshold" values would probably be less than what was chosen, such that the parameter variations used in this test would constitute an upper bound for the actual "threshold" values.

\section{B. Test Configuration}

This sensitivity study was conducted in the NASA Glenn Icing Research Tunnel (IRT) which is a closed-loop refrigerated wind tunnel. The test section is $6 \mathrm{ft}(1.83 \mathrm{~m})$ high and $9 \mathrm{ft}(2.74 \mathrm{~m})$ wide, and contains a turntable assembly which allows for model angle-of-attack changes. A $5000 \mathrm{hp}$ fan provides airspeeds up to $390 \mathrm{mph}$ (empty test section). The refrigeration heat exchanger can control air temperature from $+40^{\circ} \mathrm{F}\left(4.4^{\circ} \mathrm{C}\right)$ to $-20^{\circ} \mathrm{F}\left(-28.9^{\circ} \mathrm{C}\right)$.

The water spray system has been calibrated for simulating icing clouds with droplet MVD of 10 to $216 \mu \mathrm{m}$, and Liquid Water Content (LWC) of $0.2-3.4 \mathrm{~g} / \mathrm{m}^{3}$. Figure 1 shows a schematic view of the IRT. 


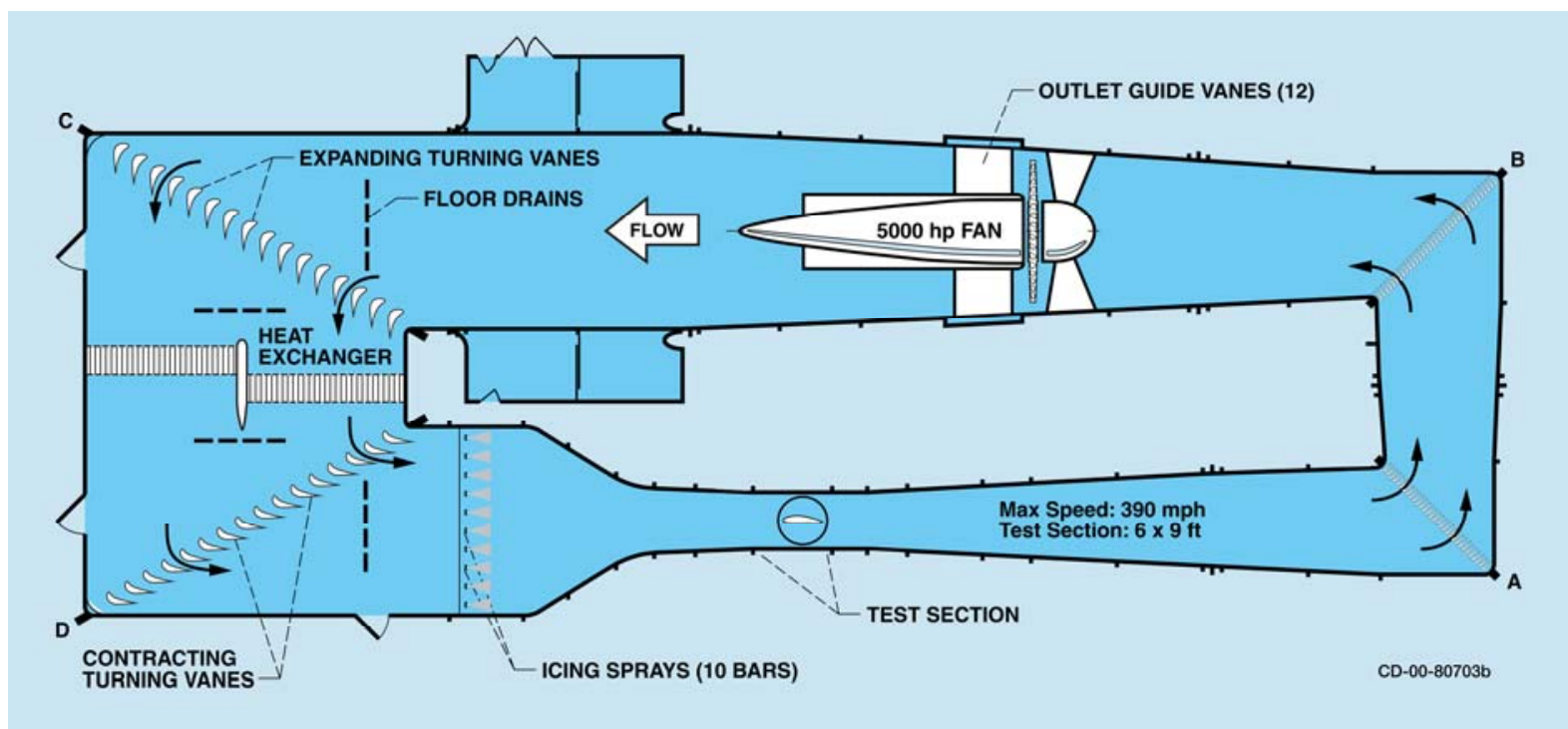

Figure 1. NASA Glenn Icing Research Tunnel

The test article was a 3 foot $(0.914 \mathrm{~m})$ chord NACA-0012 airfoil having a 6 foot $(1.83 \mathrm{~m})$ span. It was mounted vertically in the test section, and was fixed at a $2.5^{\circ}$ angle-of attack for all the conditions tested. A heater mat was installed on the model to assist in removing the ice accretion and making mass measurements. The heater mat extended 11 inches $(0.28 \mathrm{~m})$ above and below the vertical centerline of the tunnel (which was at 3 feet $(0.914 \mathrm{~m})$ from the floor), and wrapped around 3.5 inches $(0.089 \mathrm{~m})$ on the upper surface of the airfoil, and 8.5 inches $(0.216 \mathrm{~m})$ on the lower surface. The $2.5^{\circ}$ AOA was chosen to provide some difference between the upper and lower surface ice shapes of this symmetrical airfoil. The test article is shown installed in the IRT test section in Fig. 2.

\section{Test Conditions}

The parameters of primary interest in this study were LWC, MVD, and temperature. Since it was recognized that temperature can have a significant effect on the ice shape features, depending on the icing regime (e.g. - glaze, mixed, rime), it was decided to evaluate the effect of all three parameters at two freezing fractions of 0.3, and 0.7. Additionally, it was decided to conduct the sensitivity study at two airspeeds of 130 knots and 180 knots, for the purpose of evaluating the relative significance of airspeed as a parameter. Since the variation of LWC, MVD, and temperature on the resulting ice shape was evaluated at two airspeeds, and two freezing fractions, one could essentially organize the sensitivity study into 4 separate sub-tests

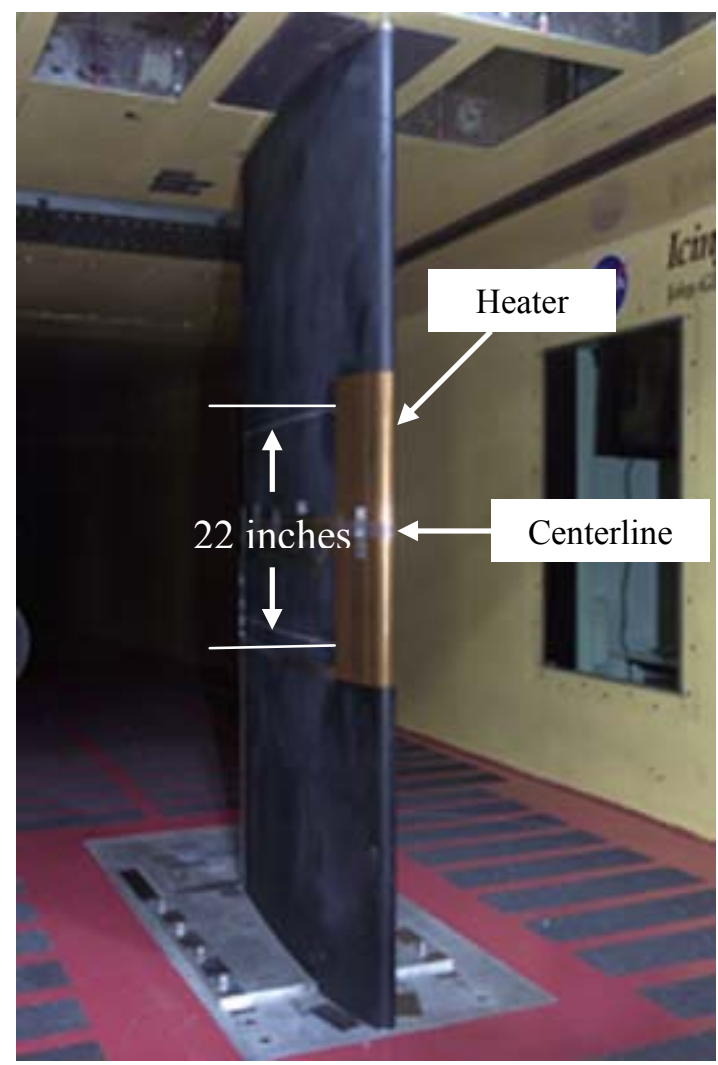

Figure 2. NACA-0012 airfoil installed in the test section of the NASA IRT 
distinguished by freezing fraction and airspeed: $\eta=0.3 \& \mathrm{~V}=130$ knots, $\eta=0.3 \& \mathrm{~V}=180$ knots, $\eta=0.7 \& \mathrm{~V}=$ 130 knots, and $\eta=0.7 \& \mathrm{~V}=180$ knots. The test conditions for each of the four sub-test categories are listed below:

Sub-Test \#1:

$\mathrm{LWC}=\mathbf{0 . 6} \mathbf{g} / \mathbf{m}^{3}+/-0.1 \mathrm{~g} / \mathrm{m}^{3}, \mathrm{MVD}=\mathbf{8 0} \boldsymbol{\mu m}+/-50 \mu \mathrm{m}, \mathrm{T}_{\mathrm{s}}=\mathbf{1 9 . 5 ^ { \circ }} \mathbf{F}+/-3^{\circ} \mathrm{F}$ for $\eta=0.3, \mathrm{~V}=130 \mathrm{knots}$

Sub-Test \#2:

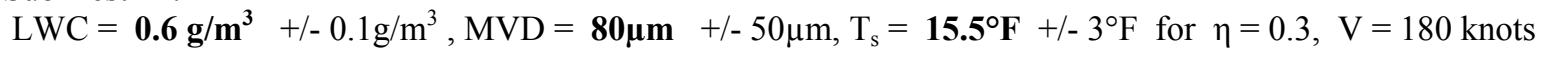

Sub-Test \#3:

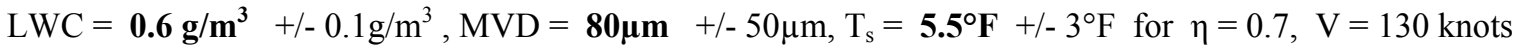

Sub-Test \#4:

$\mathrm{LWC}=\mathbf{0 . 6} \mathbf{g} / \mathbf{m}^{3}+/-0.1 \mathrm{~g} / \mathrm{m}^{3}, \mathrm{MVD}=\mathbf{8 0} \boldsymbol{\mu m}+/-50 \mu \mathrm{m}, \mathrm{T}_{\mathrm{s}}=\mathbf{- 0 . 5}{ }^{\circ} \mathbf{F}+/-3^{\circ} \mathrm{F}$ for $\eta=0.7, \mathrm{~V}=180 \mathrm{knots}$

Supporting rationale for these parameter choices are further described below:

1. $L W C$

Flight research aircraft have measured nominal LWC of $0.3 \mathrm{~g} / \mathrm{m}^{3}$ in SLD icing conditions, with maximum values ranging to $0.5 \mathrm{~g} / \mathrm{m}^{3}$. The nominal value of $0.6 \mathrm{~g} / \mathrm{m}^{3}$ was selected in an attempt to select a nominal LWC as close to flight results as possible, yet still remain within the IRT's capability. The variation of $+/-0.1 \mathrm{~g} / \mathrm{m}^{3}$ was chosen based on the thought it might be representative of a 15 percent LWC measurement error, which would correspond to a practical uncertainty associated with hot-wire LWC instrumentation. ${ }^{4,5}$

\section{2. $M V D$}

The MVD variation was chosen on a slightly different basis than LWC or temperature variations. It was not related to an instrumentation uncertainty, as were LWC and temperature variations, but was selected to allow a wide range of MVD variation. A nominal MVD of $80 \mu \mathrm{m}$ was selected to be within the large droplet portion of the IRT spray capability. Then a $50 \mu \mathrm{m}$ parameter variation was chosen to allow drop size variation into the Appendix $\mathrm{C}$ regime, and also to larger drop sizes within the IRT's large droplet capability. Due to facility constraints trying to simultaneously match MVD, LWC, and airspeed, it was necessary to select $28 \mu \mathrm{m}$ instead of $30 \mu \mathrm{m}$, for the minimum drop size in this study. It should be noted that the $50 \mu \mathrm{m}$ parameter variation constituted 60 percent of the nominal value.

\section{Temperature}

Since it was recognized that temperature had a very significant effect on ice shape features, it was decided to conduct the sensitivity study at a freezing fraction $\eta$ of 0.3 and 0.7 . The concept of freezing fraction, first proposed by Messinger, provides a convenient mechanism to account for the thermodynamics of the different icing regimes on the leading edge of an airfoil $(\eta=1.0$.. rime, $\eta \sim 0.1$.. glaze). For this study, it was decided to select one freezing fraction more toward the rime category, and the other freezing fraction more toward the glaze category. It should be mentioned that when a parameter was varied, the freezing fraction was not maintained at a value of 0.3, or 0.7. Those freezing fractions only applied to the nominal condition. However for convenience, results from variant conditions have been associated with the freezing fraction of the nominal condition when listed in tables or referred to in figures.

The nominal values of Ts for this sensitivity study were determined with the aid of LEWICE 2.0 using the following procedure:

- First, the nominal LWC, MVD, airspeed, and AOA and an initial static temperature $\mathrm{T}_{\mathrm{s}}$ guess (to yield the desired freezing fraction) were input to LEWICE 2.0

- LEWICE was run with those inputs for a 1 minute time period.

- The value of freezing fraction $\eta$ computed for the stagnation point was then compared with the desired freezing fraction

- If the computed freezing fraction differed from the desired value, $\mathrm{T}_{\mathrm{s}}$ was adjusted and LEWICE was rerun again to compute a new freezing fraction at the stagnation point of the test article

- This process was repeated until the desired and computed freezing fractions agreed

The $3{ }^{\circ} \mathrm{F}$ variation was chosen based on what was believed to be an estimate of a worst case end-to-end uncertainty associated with a thermocouple based temperature measurement system (where end-to-end refers to the complete signal path from sensor -to- signal conditioning -to- computer output). This estimate assumes $+/-1^{\circ} \mathrm{F}$ 
variation attributed to wiring and signal conditioning, and $+/-2{ }^{\circ} \mathrm{F}$ variation for sensor accuracy and artifacts introduced in the measurement by the specific sensor installation.

\section{Test Procedure}

The following test procedure was used for each of the test runs in this investigation.

- Baseline and variation conditions were used to set tunnel operating values (i.e. tunnel velocity, air temperature, spray bar air and water pressures)

- Icing conditions were applied for the selected spray times

- After the spray was concluded and the tunnel velocity was set to idle:

- Photographs of the ice accretion were taken

- An ice shape tracing was made at the mid-span location

- The ice was cut at predetermined span-wise locations above and below mid-span

- Heaters were turned on to de-bond the ice from the surface

- Ice was removed and weighed

Table 1. Sensitivity study experimental icing runs

\begin{tabular}{|c|c|c|c|c|c|c|c|c|c|c|c|c|}
\hline Description & Run & $\eta$ & $\begin{array}{c}\mathrm{V} \\
\text { (knots) }\end{array}$ & $\begin{array}{l}\text { LWC } \\
\left(\mathrm{g} / \mathrm{m}^{3}\right)\end{array}$ & $\begin{array}{l}\text { MVD } \\
(\mu \mathrm{m})\end{array}$ & $\begin{array}{l}\text { Ttot } \\
\left({ }^{\circ} \mathrm{F}\right)\end{array}$ & $\begin{array}{l}\text { Ts } \\
\left({ }^{\circ} \mathrm{F}\right)\end{array}$ & $\begin{array}{c}\text { AOA } \\
\text { (degrees) }\end{array}$ & $\begin{array}{l}\text { Mass } \\
(\mathrm{gm})\end{array}$ & $\begin{array}{l}\text { Spray } \\
\text { Time } \\
\text { (min) }\end{array}$ & $\begin{array}{l}\text { Pair } \\
\text { (psi) }\end{array}$ & $\begin{array}{c}\Delta \mathrm{P} \\
\text { (psi) }\end{array}$ \\
\hline nominal & 1 & 0.3 & 130 & 0.6 & 80 & 23.5 & 19.5 & 2.5 & 845.6 & 20 & 4.5 & 19.1 \\
\hline repeat run & 2 & 0.3 & 130 & 0.6 & 80 & 23.5 & 19.5 & 2.5 & 882.9 & 20 & 4.5 & 19.1 \\
\hline LWC - 0.1 & 3 & & & 0.5 & $"$ & $"$ & $"$ & $"$ & 740.9 & $"$ & 3.4 & 12.4 \\
\hline LWC +0.1 & 4 & & & 0.7 & $"$ & " & $"$ & $"$ & 1027.5 & " & 6.0 & 28.2 \\
\hline MVD - 52 & 5 & & & 0.6 & 28 & $"$ & $"$ & $"$ & 715.9 & $"$ & 10.1 & 30.3 \\
\hline MVD + 50 & 6 & & & $"$ & 130 & $"$ & $"$ & $"$ & 1081.2 & $"$ & 2.5 & 14.8 \\
\hline Temp - 3 & 7 & & & $"$ & 80 & 20.5 & 16.5 & $"$ & 862.2 & $"$ & 4.5 & 19.1 \\
\hline Temp +3 & 9 & & & $"$ & $"$ & 26.5 & 22.5 & $"$ & 877.9 & $"$ & 4.5 & 19.1 \\
\hline nominal & 10 & 0.7 & 130 & 0.6 & 80 & 9.5 & 5.5 & 2.5 & 1059.9 & 20 & 4.5 & 19.1 \\
\hline repeat run & 11 & 0.7 & 130 & 0.6 & 80 & 9.5 & 5.5 & 2.5 & 1102.5 & 20 & 4.5 & 19.1 \\
\hline LWC - 0.1 & 12 & & & 0.5 & $"$ & $"$ & $"$ & $"$ & 970.7 & $"$ & 3.4 & 12.4 \\
\hline $\mathrm{LWC}+0.1$ & 13 & & & 0.7 & $"$ & $"$ & $"$ & $"$ & 1241.9 & $"$ & 6.0 & 28.2 \\
\hline MVD - 52 & 14 & & & 0.6 & 28 & $"$ & $"$ & $"$ & 838.9 & $"$ & 10.1 & 30.3 \\
\hline $\mathrm{MVD}+50$ & 15 & & & $"$ & 130 & $"$ & $"$ & $"$ & 1458.8 & $"$ & 2.5 & 14.8 \\
\hline Temp - 3 & 16 & & & $"$ & 80 & 6.5 & 2.5 & $"$ & 1168.2 & $"$ & 4.5 & 19.1 \\
\hline Temp +3 & 17 & & & $"$ & $"$ & 12.5 & 8.5 & $"$ & 1058.1 & $"$ & 4.5 & 19.1 \\
\hline nominal & 18 & 0.3 & 180 & 0.6 & 80 & 23.2 & 15.5 & 2.5 & 784.2 & 13.6 & 8.2 & 42.2 \\
\hline repeat run & 19 & 0.3 & 180 & 0.6 & 80 & 23.2 & 15.5 & 2.5 & 763.5 & 13.6 & 8.2 & 42.2 \\
\hline LWC - 0.1 & 20 & & & 0.5 & $"$ & $"$ & $"$ & $"$ & 649.6 & $"$ & 5.6 & 25.8 \\
\hline $\mathrm{LWC}+0.1$ & 21 & & & 0.7 & $"$ & $"$ & $"$ & $"$ & 1016.5 & $"$ & 10 & 65 \\
\hline MVD - 52 & 22 & & & 0.6 & 28 & $"$ & $"$ & $"$ & 611.2 & $"$ & 13.2 & 47.9 \\
\hline $\mathrm{MVD}+50$ & 23 & & & $"$ & 130 & $"$ & $"$ & $"$ & 844.8 & $"$ & 3.7 & 27 \\
\hline Temp - 3 & 24 & & & $"$ & 80 & 20.2 & 12.5 & $"$ & 785.1 & $"$ & 8.2 & 42 \\
\hline Temp +3 & 25 & & & $"$ & $"$ & 26.2 & 18.5 & $"$ & 755.1 & $"$ & 8.2 & 42 \\
\hline nominal & 27 & 0.7 & 180 & 0.6 & 80 & 7.2 & -0.5 & 2.5 & 1009.1 & 13.6 & 8.2 & 42.2 \\
\hline repeat run & 28 & 0.7 & 180 & 0.6 & 80 & 7.2 & -0.5 & 2.5 & 1014.3 & 13.6 & 8.2 & 42.2 \\
\hline LWC - 0.1 & 29 & & & 0.5 & $"$ & $"$ & $"$ & $"$ & 818.9 & $"$ & 5.6 & 25.8 \\
\hline $\mathrm{LWC}+0.1$ & 30 & & & 0.7 & $"$ & $"$ & $"$ & $"$ & 1424.3 & $"$ & 10 & 65 \\
\hline MVD - 52 & 31 & & & 0.6 & 28 & $"$ & $"$ & $"$ & 684.1 & $"$ & 13.2 & 47.9 \\
\hline $\mathrm{MVD}+50$ & 32 & & & $"$ & 130 & $"$ & $"$ & $"$ & 1275.4 & $"$ & 3.7 & 27 \\
\hline Temp - 3 & 33 & & & $"$ & 80 & 4.2 & -3.5 & $"$ & 1099.1 & $"$ & 8.2 & 42 \\
\hline Temp +3 & 34 & & & " & " & 10.2 & 2.5 & " & 1058.6 & $"$ & 8.2 & 42 \\
\hline
\end{tabular}

Note: accumulation parameter was held constant for the two airspeeds, which resulted in different spray times 


\section{Results and Discussion}

The experimental icing runs conducted in the NASA-Glenn IRT as part of this sensitivity investigation are listed in Table 1. The tunnel and icing spray conditions are tabulated for each run, along with the mass of the ice accretion removed from the area of the model covered by the heater mat. This section will present selected results, and describe the qualitative and quantitative analysis applied to these results. The ice shape repeatability will be considered, followed by an assessment of LWC, MVD, and temperature variations on the resulting ice shapes. Though the study was done at two airspeeds, space limitations allow us to present only the data for one airspeed. Since, the higher airspeed was closer to actual aircraft speeds, it was thought these results might have more relevance to aircraft icing. Therefore, only the 180 knot cases will be presented and discussed.

\section{A. Ice Shape Repeatability}

There is an inherent level of variation to ice shapes produced in an icing wind tunnel. Since this study intended to evaluate the effects of parameter changes on the resulting ice accretion, it was important to determine what level of change in ice shape features (general shape, horn location, mass...etc) could be expected due to the normal run to run variations of the icing spray condition. Obviously, less ice shape variation (better repeatability) would be more desirable because it would facilitate the evaluation of the effects of smaller parameter changes.

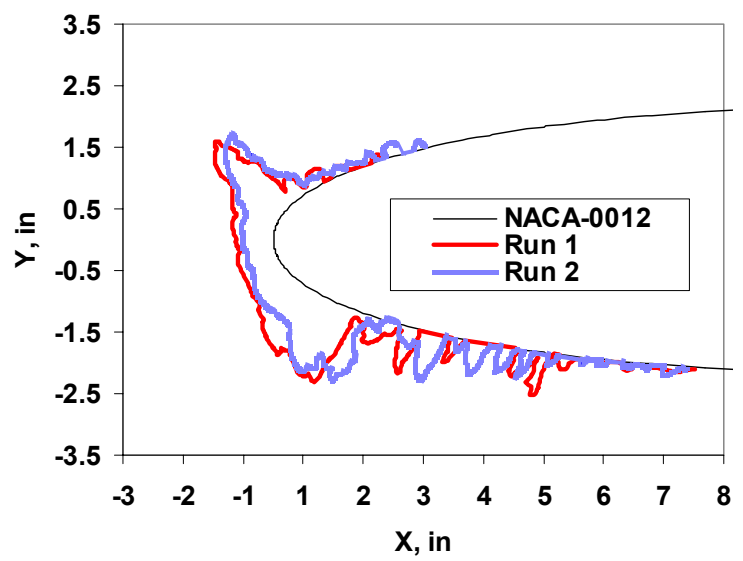

c) $\eta=0.3, V=130$ knots, $\mathrm{Ts}=19.5^{\circ} \mathrm{F}$, $\mathrm{LWC}=0.6 \mathrm{~g} / \mathrm{m}^{3}, \mathrm{MVD}=80 \mu \mathrm{m}, \mathrm{AOA}=2.5^{\circ}$

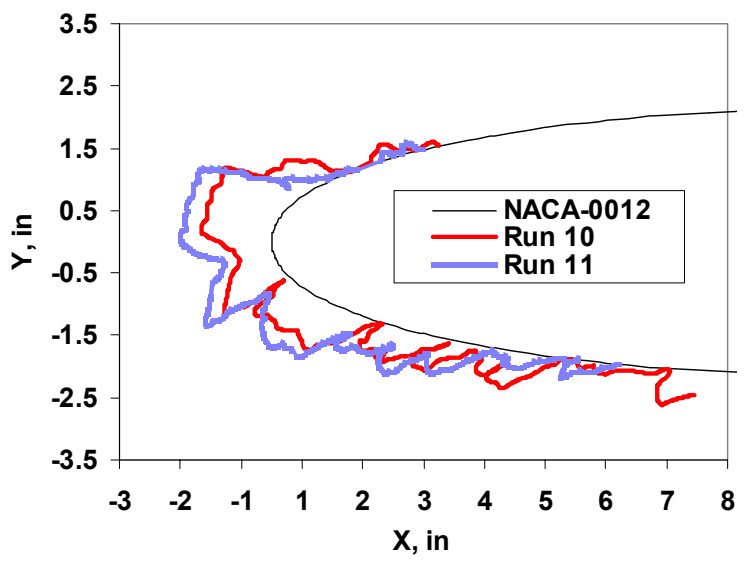

a) $\eta=0.7, \mathrm{~V}=130$ knots, $\mathrm{Ts}=5.5^{\circ} \mathrm{F}$ $\mathrm{LWC}=0.6 \mathrm{~g} / \mathrm{m}^{3}, \mathrm{MVD}=80 \mu \mathrm{m}, \mathrm{AOA}=2.5^{\circ}$

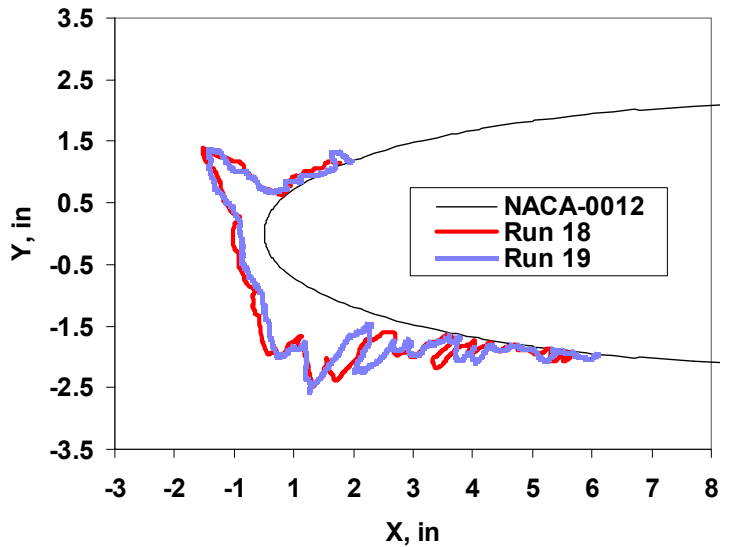

d) $\eta=0.3, V=180$ knots, $\mathrm{Ts}=15.5^{\circ} \mathrm{F}$, $\mathrm{LWC}=0.6 \mathrm{~g} / \mathrm{m}^{3}, \mathrm{MVD}=80 \mu \mathrm{m}, \mathrm{AOA}=2.5^{\circ}$

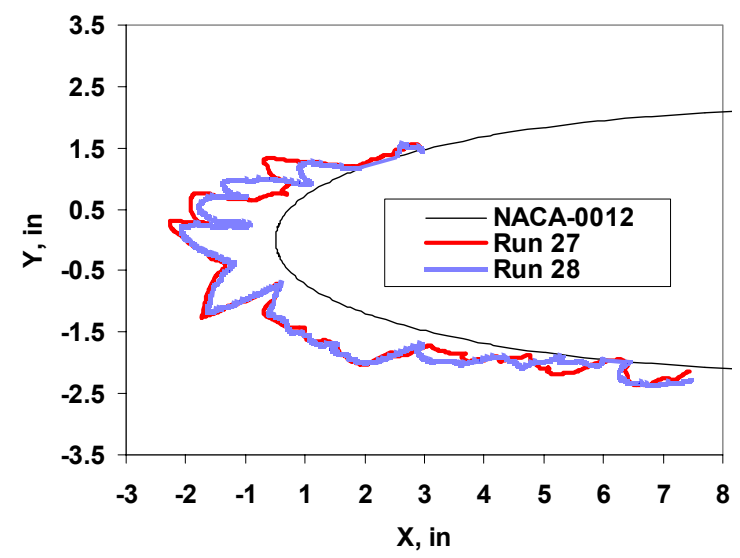

b) $\eta=0.7, \mathrm{~V}=180$ knots, $\mathrm{Ts}=-0.5^{\circ} \mathrm{F}$

$\mathrm{LWC}=0.6 \mathrm{~g} / \mathrm{m}^{3}, \mathrm{MVD}=80 \mu \mathrm{m}, \mathrm{AOA}=2.5^{\circ}$

Figure 3. Ice shape repeatability for repeat runs of the 4 nominal sub-test conditions. 


\section{Qualitative Evaluation}

Figure 3 shows ice tracing comparisons from repeat runs of the nominal spray condition having an LWC of $0.6 \mathrm{~g} / \mathrm{m}^{3}$ and an MVD of $80 \mu \mathrm{m}$. These ice tracings were obtained at two freezing fractions $(\eta=0.3$ and 0.7$)$, and two airspeeds ( $\mathrm{V}=130$ and 180 knots). A qualitative inspection of the tracing comparison plots in fig. 3 suggests that the repeatability was very good. Even at warmer temperature conditions $(\eta=0.3)$, there was very good agreement between the main ice shapes for both airspeed conditions (fig. 3c and 3d). The ice tracing comparison in fig. 3a shows more noticeable variation than figs. $3 \mathrm{~b}, 3 \mathrm{c}$, and $3 \mathrm{~d}$, but this is not considered significant because there may have been an issue with the ice tracing for Run 10 (inner tracing). It is believed that the cardboard ice tracing template was not pushed all the way into the ice cut on the accretion for this run, resulting in the observed variation.

\section{Quantitative Evaluation}

It was also desired to employ some quantitative means to assess changes in ice shape features in addition to qualitative comparisons. The THICK program developed by William Wright of NASA Glenn Research Center was used to perform quantitative assessment of changes in ice shape features. ${ }^{6}$ This program was originally developed and used during the validation of LEWICE. By comparing the un-iced airfoil coordinates with the digitized coordinates of an ice shape, it is capable of calculating ice shape attributes such as upper and lower surface maximum ice thickness, icing horn angle, and icing limits.

Fig. 4 shows the convention that THICK uses to determine maximum thickness and horn angle. An axis has been superimposed on the ice tracing to illustrate the coordinate system used by THICK to determine the angles of the maximum ice thickness (which THICK considers as horns) on both the upper and lower surface of the airfoil. The maximum thickness is calculated by scanning the ice shape for the location of greatest thickness normal to the surface on both the upper and lower surface of the airfoil. When a maximum thickness is found, THICK then draws a line from the origin of the axis system to the point of maximum thickness, whereupon it then calculates the associated angle as depicted in Fig. 4.

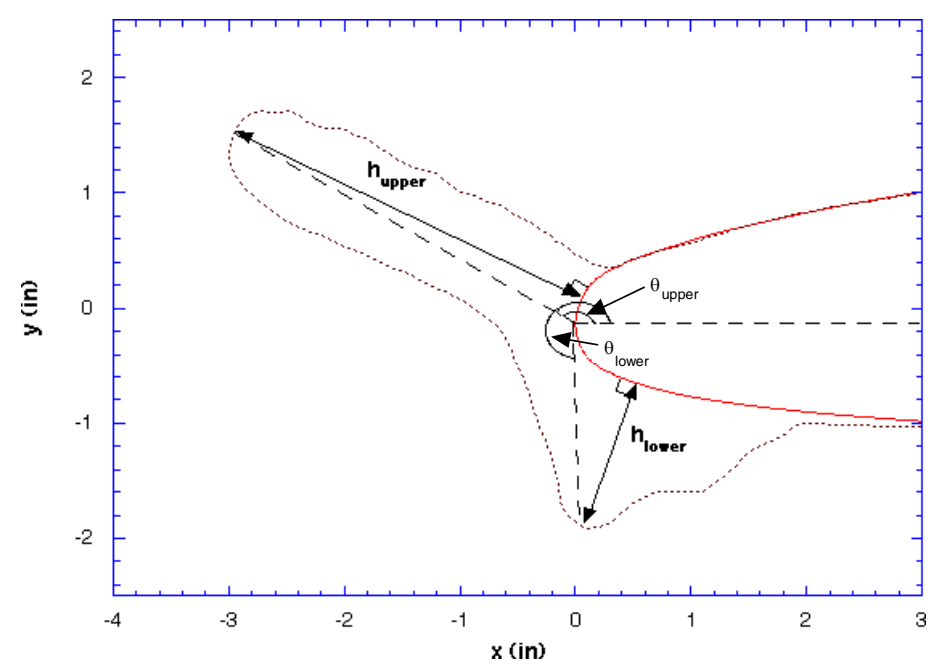

Figure 4. Diagram showing THICK computation of

THICK was used to determine the ice horn thickness, horn angle, iced area, and icing limits associated with the ice tracings shown in Figs. 3a-3d. Since each plot in Fig. 3 contained two ice tracings (representing repeat runs of

Table 2. THICK Calculations For Repeatability Of Nominal Sub-Test Conditions

\begin{tabular}{|c|c|c|c|c|c|c|c|c|c|c|c|c|}
\hline Run & $\begin{array}{c}\text { Freezing } \\
\text { Fraction } \\
\eta\end{array}$ & $\begin{array}{c}\mathrm{V} \\
\text { (knots) }\end{array}$ & $\begin{array}{l}\text { MVD } \\
(\mu \mathrm{m})\end{array}$ & $\begin{array}{l}\text { LWC, } \\
\left(\mathrm{g} / \mathrm{m}^{3}\right)\end{array}$ & $\begin{array}{l}\text { Lower } \\
\text { Icing Limit } \\
\text { (inches) }\end{array}$ & $\begin{array}{l}\text { Upper lcing } \\
\text { Limit } \\
\text { (inches) }\end{array}$ & $\begin{array}{c}\text { Lower } \\
\text { Horn } \\
\text { Thickness } \\
\text { (inches) }\end{array}$ & $\begin{array}{c}\text { Upper } \\
\text { Horn } \\
\text { Thickness } \\
\text { (inches) }\end{array}$ & $\begin{array}{c}\text { Area } \\
\left(\text { inch }^{2}\right)\end{array}$ & $\begin{array}{l}\text { Lower } \\
\text { Horn } \\
\text { Angle } \\
\text { (deg) }\end{array}$ & $\begin{array}{c}\text { Upper } \\
\text { Horn } \\
\text { Angle } \\
\text { (deg) }\end{array}$ & Mass (gm) \\
\hline 1 & 0.3 & 130 & 80 & 0.6 & -7.5 & 2.36 & 1.33 & 1.61 & 4.34 & 285.9 & 120.8 & 845.6 \\
\hline 2 & & & & & -7.77 & 3.14 & 1.25 & 1.50 & 4.27 & 281.6 & 113.5 & 882.9 \\
\hline AVG $1 \& 2$ & Nomir & lal Sub-T & st Condi & on \#1 & -7.66 & 2.75 & 1.29 & 1.56 & 4.31 & 283.8 & 117.2 & 864.3 \\
\hline STD DEV & Variatio & Of Sub- & Test Con & tion \#1 & 0.16 & 0.55 & 0.06 & 0.08 & 0.05 & 3.0 & 5.2 & 26.4 \\
\hline 18 & 0.3 & 180 & 80 & 0.6 & -5.87 & 1.83 & 1.40 & 2 & 4.20 & 288.5 & 126.1 & 784.2 \\
\hline 19 & & & & & -6.30 & 2.00 & 1.56 & 1.44 & 3.97 & 286.3 & 123.9 & 763.5 \\
\hline AVG $18 \& 19$ & Nomir & al Sub-T & st Condi & on \#2 & -6.09 & 1.91 & 1.48 & 1.48 & 4.08 & 287.4 & 125.0 & 773.9 \\
\hline STD DEV & Variatio & Of Sub & Test Con & tion \#2 & 0.31 & 0.12 & 0.12 & 0.06 & 0.17 & 1.6 & 1.6 & 14.6 \\
\hline 10 & 0.7 & 130 & 80 & 0.6 & -7.70 & 3.34 & 1.19 & 1.21 & 5.33 & 236.7 & 124.4 & 1059.9 \\
\hline 11 & & & & & -6.43 & 3.09 & 1.56 & 1.52 & 5.70 & 230.9 & 137.8 & 1102.5 \\
\hline AVG $10 \& 11$ & Nomir & Ial Sub-T & st Condi & on \#3 & -7.07 & 3.22 & 1.37 & 1.37 & 5.52 & 233.8 & 131.1 & 1081.2 \\
\hline STD DEV & Variatio & Of Sub- & Test Con & tion \#3 & 0.90 & 0.18 & 0.26 & 0.22 & 0.26 & 4.1 & 9.5 & 30.1 \\
\hline 27 & 0.7 & 130 & 80 & 0.6 & -7.67 & 3.03 & 1.63 & 1.78 & 5.72 & 225.5 & 172.1 & 1009.1 \\
\hline 28 & & & & & -7.70 & 3.06 & 1.48 & 1.59 & 5.51 & 225.2 & 172.5 & 1014.3 \\
\hline AVG $27 \& 28$ & Nomir & lal Sub-T & st Condi & on \#4 & -7.69 & 3.05 & 1.55 & 1.69 & 5.61 & 225.3 & 172.3 & 1011.7 \\
\hline STD DEV & Variatio & Of Sub- & Test Con & tion \#4 & 0.03 & 0.02 & 0.11 & 0.13 & 0.15 & 0.2 & 0.3 & 3.7 \\
\hline
\end{tabular}


the same nominal sub-test condition), THICK was run twice to get a unique value of the previously mentioned ice shape attributes. The measured mass was also included with the corresponding THICK calculations. These values were then used to determine an average and standard deviation of each ice shape attribute for each nominal sub-test condition. These results are listed in Table 2, for each of the nominal sub-test conditions.

The values in Table 2 will provide the basis for quantitatively assessing the significance of ice feature changes due to variations in LWC, MVD, and temperature later in this report. The significance of the average value of an attribute in Table 2, is that they will serve as reference or (nominal) THICK values for assessing the effect of LWC, MVD, and temperature effects. The standard deviation of an attribute in Table 2 represents the expected variation in that ice shape attribute due to icing spray repeatability for the particular nominal sub-test condition.

Inspection of the standard deviation values in Table 2, suggests that for all THICK attributes (except the icing limits) there was a relatively small variation. This is a quantitative indication of good ice shape repeatability for all the cases in Fig. 3. William Wright obtained similar results during the validation of LEWICE 2.0. ${ }^{6}$ The greater variation in the standard deviation of THICK icing limits is not totally unexpected, given the difficulties of tracing ice features near the icing limits. It is sometimes very difficult to trace small feathers far aft of the main ice shape, without them breaking off.

\section{B. Effect of Varying LWC}

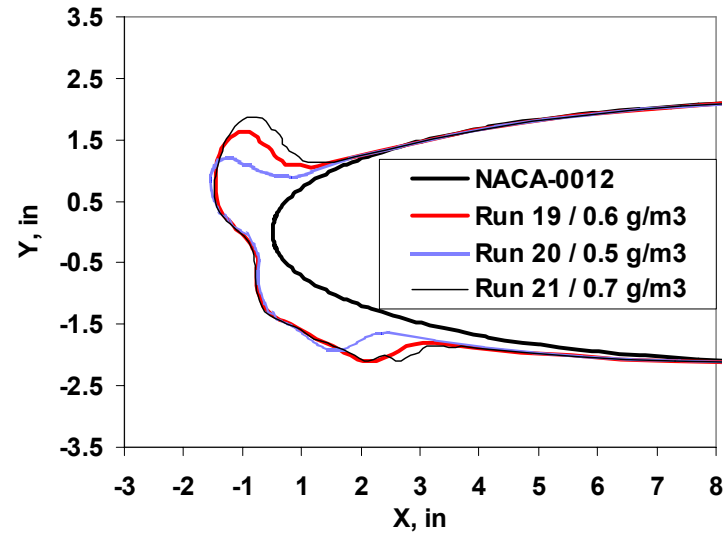

a) $\eta=0.3, V=180$ knots, $\mathrm{Ts}=15.5^{\circ} \mathrm{F}$, $\mathrm{MVD}=80 \mu \mathrm{m}, \mathrm{AOA}=2.5^{\circ}$

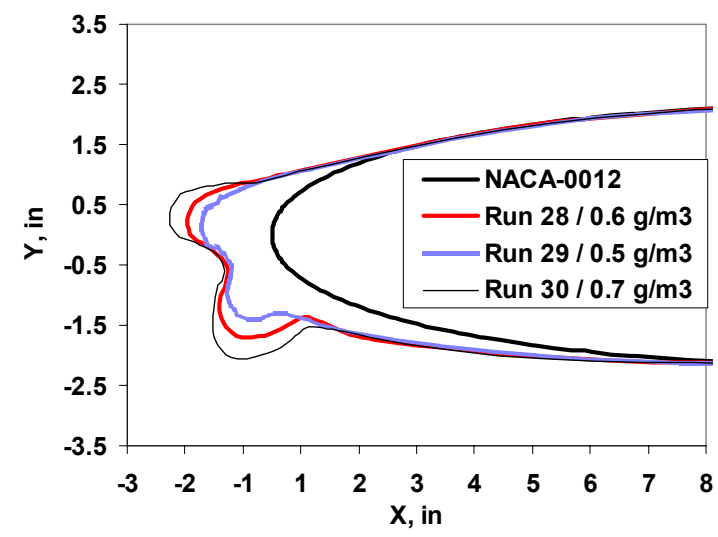

b) $\eta=0.7, \mathrm{~V}=180$ knots, $\mathrm{Ts}=-0.5^{\circ} \mathrm{F}$ $\mathrm{MVD}=80 \mu \mathrm{m}, \mathrm{AOA}=2.5^{\circ}$

Figure 5. LEWICE predictions showing the effect of LWC variations on ice shape.

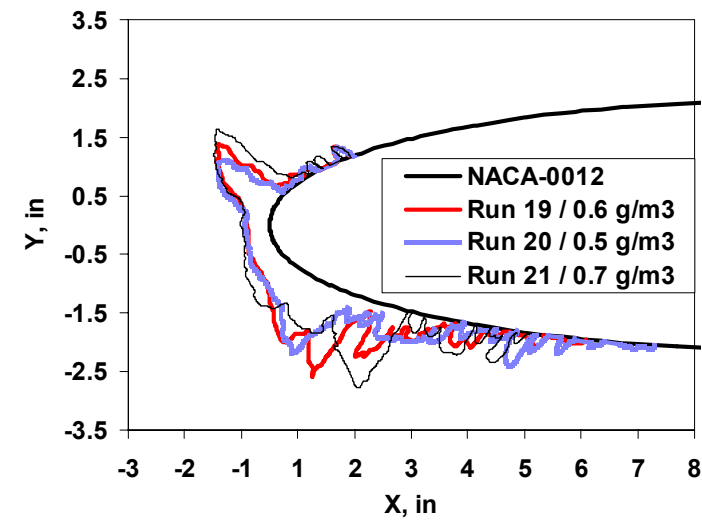

a) $\eta=0.3, V=180$ knots, $\mathrm{Ts}=15.5^{\circ} \mathrm{F}$, $\mathrm{MVD}=80 \mu \mathrm{m}, \mathrm{AOA}=2.5^{\circ}$

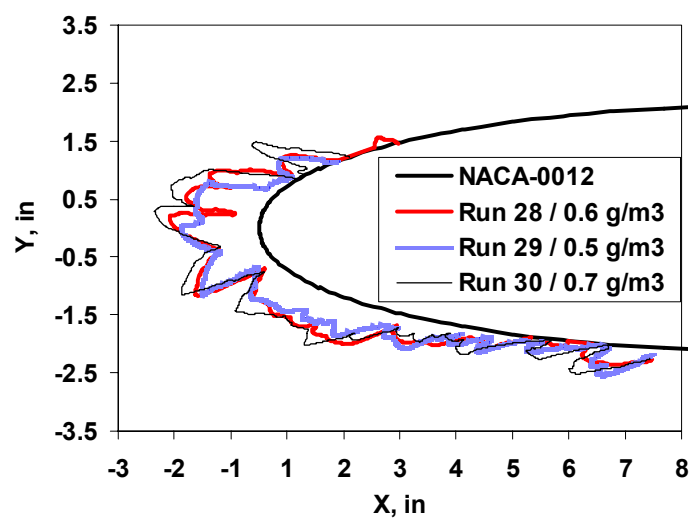

b) $\eta=0.7, V=180$ knots, $T s=-0.5^{\circ} \mathrm{F}$ $\mathrm{MVD}=80 \mu \mathrm{m}, \mathrm{AOA}=2.5^{\circ}$

Figure 6. Change in ice shape tracings due to $L W C$ variation at $\eta=0.3$ and 0.7 


\section{Computational Trend Prediction}

Since, it was known that freezing fraction had a significant effect on ice shape features, the effect of LWC variations on ice shapes was evaluated at two freezing fractions of 0.3 and 0.7 . To get a sense of how ice shape features might change as a result of LWC variations, LEWICE 2.0 was run with the appropriate input conditions from Table 1. The predicted ice shapes for a 180 knot airspeed are shown in Fig. 5.

Figure 5 illustrates the effect of LWC variation on predicted ice shapes for LWC variations of $+/-0.1 \mathrm{~g} / \mathrm{m}^{3}$ about a nominal condition of $0.6 \mathrm{~g} / \mathrm{m}^{3}$. The effect of freezing fraction on ice shape feature changes can be seen by comparing Fig. 5 a where $\eta=0.3$, with Fig. $5 b$ where $\eta=0.7$. Some qualitative observations can be made about expected ice shape changes based on Fig. 5.

For a freezing fraction of 0.3 , it appears as if:

- The thickness of the flat area main ice shape remains the same regardless of LWC.

- As LWC is increased the upper horns grow larger, and rotate aft (decrease in THICK horn angle).

- The main ice shape extends further aft on the lower surface as the LWC is increased.

- The mass and area of the main ice shape increase as LWC is increased.

For a freezing fraction of 0.7 , it appears as if:

- Ice horn thickness increases as LWC increases.

- The upper ice horn angle doesn't appear to change much.

- The lower ice horn angle appears to rotate aft a bit.

- The area of the main ice shape increases with increasing LWC.

The LEWICE results suggest that the $+/-0.1 \mathrm{~g} / \mathrm{m}^{3} \mathrm{LWC}$ variation should yield discernible changes in ice shape features, and that the type and degree of feature changes appear to be affected by the freezing fraction.

\section{Qualitative Assessment Of Actual Ice Shapes}

Fig. 6 illustrates the effect of LWC variation on actual ice shapes for LWC variations of $+/-0.1 \mathrm{~g} / \mathrm{m}^{3}$ about a nominal condition of $0.6 \mathrm{~g} / \mathrm{m}^{3}$. The effect of freezing fraction on ice shape feature changes can be seen by comparing Fig. 6 a where $\eta=0.3$, with Fig. $6 \mathrm{~b}$ where $\eta=0.7$.

Examination of the ice shape tracings in Fig. 6a and Fig. $6 \mathrm{~b}$ exhibited similar trends to what was predicted by LEWICE. Since LEWICE doesn't model feather growth, there were some expected differences between the actual and predicted ice shapes. Some of these differences between predicted and observations about actual ice shape changes are listed below.

For a freezing fraction of 0.3 :

- The thickness of the flat area of the main ice shape remained about constant (regardless of LWC) near the stagnation line, but the thickness began to change as a function of LWC as you moved toward the lower surface

- As LWC was increased, the lower surface horns became thicker, and appeared to rotate aft. The differences in horn thickness and rotation appeared to be greater when comparing the nominal condition $\left(0.6 \mathrm{~g} / \mathrm{m}^{3}\right)$ to the high LWC condition $\left(0.5 \mathrm{~g} / \mathrm{m}^{3}\right)$, versus comparing the nominal condition to the low LWC condition $\left(0.5 \mathrm{~g} / \mathrm{m}^{3}\right)$.

- The lower icing limit appeared to move forward as LWC was increased

For a freezing fraction of 0.7 :

- In general, there seemed to be less relative change in ice shape features as LWC was varied, than the LEWICE predictions.

- The presence of large ice feathers was evident on the actual ice tracings at this freezing fraction.

- Both the upper and lower ice horn angles didn't appear to change significantly with changes in LWC.

Based on the above qualitative assessment, it can be said that a $+/-0.1 \mathrm{~g} / \mathrm{m}^{3}$ variation in LWC produced visually observable changes in ice shape features, and that the freezing fraction affected the degree to which these feature changes were manifested.

\section{Quantitative Assessment Of Actual Ice Shapes}

Given the qualitative assessment above, it was next desired to quantitatively evaluate changes in ice shape features due to variations in LWC. The THICK program was used to quantify ice shape features and the change in these features as the LWC was varied $+/-0.1 \mathrm{gm} / \mathrm{m}^{3}$ about the nominal LWC of $0.6 \mathrm{gm} / \mathrm{m}^{3}$. Tables 3 and 4 contain the results of the THICK analysis for $\eta=0.3$ and $\eta=0.7$ respectively. Each table shows the THICK calculated ice shape attributes for the low LWC condition $0.5 \mathrm{~g} / \mathrm{m}^{3}$, the nominal LWC condition $0.6 \mathrm{~g} / \mathrm{m}^{3}$, and the high LWC 
condition $0.7 \mathrm{~g} / \mathrm{m}^{3}$ on the top 3 rows of the table. The ice shape tracings in Figs. 5 and 6 were input to the THICK program to generate these values. Though the mass was included in these tables, it was directly measured by removing the ice accretion over a known part of the airfoil, and then directly weighing it. Thus it was not calculated by THICK.

It should be noted that the THICK calculations for the nominal condition are actually an average of THICK values from repeat runs of the nominal condition (this was discussed earlier in the section of this paper dealing with repeatability). In addition, a standard deviation was determined from the THICK calculations for those repeat runs.

The standard deviation was intended to provide a "threshold" value by which to judge if the change in a THICK ice shape attribute could be considered significant. The rationale for this was that the standard deviation of an ice shape attribute essentially represented it's inherent variability due to variations in the icing spray condition from run to run (i.e., spray condition repeatability). The standard deviation for each ice shape attribute is listed in the second row from the bottom of each table.

The lower 3 rows of each table show the calculated change of an ice shape attribute with respect to it's value at the nominal condition. The absolute value of these changes was compared with the standard deviation, and wherever the change exceeded the standard deviation, it was highlighted. It should be mentioned that the following convention applies to the data in the tables below: (1) positive change in icing limit on upper surface $=$ aft movement, (2) positive change in icing limit on lower surface = forward movement, and (3) + change in horn angle = counter-clockwise rotation.

Table 3. Thick Calculations For Ice Shape Changes Due To LWC Variation At $\eta=0.3$

\begin{tabular}{|c|c|c|c|c|c|c|c|c|c|c|c|c|}
\hline Description & Run & $\eta$ & $\begin{array}{c}\mathrm{V} \\
\text { (knots) }\end{array}$ & $\begin{array}{l}\text { LWC, } \\
\left(\mathrm{g} / \mathrm{m}^{3}\right)\end{array}$ & $\begin{array}{c}\text { Lower } \\
\text { Icing } \\
\text { Limit } \\
\text { (inches) }\end{array}$ & $\begin{array}{c}\text { Upper } \\
\text { Icing } \\
\text { Limit } \\
\text { (inches) }\end{array}$ & $\begin{array}{c}\text { Lower } \\
\text { Horn } \\
\text { Thickness } \\
\text { (inches) }\end{array}$ & $\begin{array}{c}\text { Upper } \\
\text { Horn } \\
\text { Thickness } \\
\text { (inches) }\end{array}$ & $\begin{array}{c}\text { Area } \\
\left(\text { inch }^{2}\right)\end{array}$ & $\begin{array}{c}\text { Lower } \\
\text { Horn } \\
\text { Angle } \\
\text { (deg) }\end{array}$ & $\begin{array}{l}\text { Upper } \\
\text { Horn } \\
\text { Angle } \\
\text { (deg) }\end{array}$ & $\begin{array}{c}\text { Mass } \\
(\mathrm{gm})\end{array}$ \\
\hline \multirow{3}{*}{$\begin{array}{l}\text { THICK } \\
\text { Values }\end{array}$} & 20 & & & 0.5 & -7.5 & 2.029 & 1.340 & 1.248 & 3.65 & 279.7 & 131.6 & 649.6 \\
\hline & Nominal & 0.3 & 180 & 0.6 & -6.09 & 1.91 & 1.48 & 1.48 & 4.08 & 287.4 & 125.0 & 773.9 \\
\hline & 21 & & & 0.7 & -5.23 & 1.97 & 1.49 & 1.620 & 4.79 & 298.9 & 119.6 & 1016.5 \\
\hline \multirow{3}{*}{$\begin{array}{c}\text { Delta } \\
\text { WRT } \\
\text { Nominal }\end{array}$} & 20 & & & -0.1 & -1.42 & 0.11 & -0.14 & -0.232 & -0.44 & -7.7 & 6.6 & -124.3 \\
\hline & Nominal & 0.3 & 180 & 0.0 & 0.00 & 0.00 & 0.00 & 0 & 0.00 & 0.0 & 0.0 & 0.0 \\
\hline & 21 & & & 0.1 & 0.86 & 0.06 & 0.01 & 0.14 & 0.71 & 11.5 & -5.4 & 242.7 \\
\hline \multirow{2}{*}{$\begin{array}{l}\text { Nominal } \\
\text { Condition }\end{array}$} & Runs 18\&19 & & & Std Dev & 0.31 & 0.12 & 0.12 & 0.06 & 0.17 & 1.6 & 1.6 & 14.6 \\
\hline & Runs $18 \& 19$ & & & Average & -6.09 & 1.91 & 1.48 & 1.48 & 4.08 & 287.4 & 125.0 & 773.9 \\
\hline
\end{tabular}

Table 4. Thick Calculations For Ice Shape Changes Due To LWC Variation At $\boldsymbol{\eta}=0.7$

\begin{tabular}{|c|c|c|c|c|c|c|c|c|c|c|c|c|}
\hline Description & Run & $\eta$ & $\begin{array}{c}\mathrm{V} \\
\text { (knots) }\end{array}$ & $\begin{array}{l}\text { LWC, } \\
\left(\mathrm{g} / \mathrm{m}^{3}\right)\end{array}$ & $\begin{array}{c}\text { Lower } \\
\text { Icing } \\
\text { Limit } \\
\text { (inches) }\end{array}$ & $\begin{array}{c}\text { Upper } \\
\text { Icing } \\
\text { Limit } \\
\text { (inches) }\end{array}$ & $\begin{array}{c}\text { Lower } \\
\text { Horn } \\
\text { Thickness } \\
\text { (inches) }\end{array}$ & $\begin{array}{c}\text { Upper } \\
\text { Horn } \\
\text { Thickness } \\
\text { (inches) }\end{array}$ & $\begin{array}{c}\text { Area } \\
\left(\text { inch }^{2}\right)\end{array}$ & $\begin{array}{l}\text { Lower } \\
\text { Horn } \\
\text { Angle } \\
\text { (deg) } \\
\end{array}$ & $\begin{array}{l}\text { Upper } \\
\text { Horn } \\
\text { Angle } \\
\text { (deg) } \\
\end{array}$ & $\begin{array}{c}\text { Mass } \\
(\mathrm{gm})\end{array}$ \\
\hline \multirow{3}{*}{$\begin{array}{l}\text { THICK } \\
\text { Values }\end{array}$} & 29 & & & 0.5 & -7.73 & 1.94 & 1.38 & 1.40 & 4.81 & 228.0 & 178.9 & 818.9 \\
\hline & Nominal & 0.7 & 180 & 0.6 & -7.69 & 3.05 & 1.55 & 1.69 & 5.61 & 225.3 & 172.3 & 1011.7 \\
\hline & 30 & & & 0.7 & -7.67 & 2.16 & 1.67 & 1.87 & 6.56 & 220.2 & 171.0 & 1424.3 \\
\hline \multirow{3}{*}{$\begin{array}{c}\text { Delta } \\
\text { WRT } \\
\text { Nominal } \\
\end{array}$} & 29 & & & -0.1 & -0.04 & -1.11 & -0.17 & -0.29 & -0.81 & 2.7 & 6.6 & -192.8 \\
\hline & Nominal & 0.7 & 180 & 0.0 & 0.00 & 0.00 & 0.00 & 0.00 & 0.00 & 0.0 & 0.0 & 0.0 \\
\hline & 30 & & & 0.1 & 0.02 & -0.89 & 0.12 & 0.18 & 0.94 & -5.1 & -1.3 & 412.6 \\
\hline Nominal & Runs 27\&28 & & & Std Dev & 0.03 & 0.02 & 0.11 & 0.13 & 0.15 & 0.2 & 0.3 & 3.7 \\
\hline Condition & Runs 27\&28 & & & Average & -7.69 & 3.05 & 1.55 & 1.69 & 5.61 & 225.3 & 172.3 & 1011.7 \\
\hline
\end{tabular}

THICK values in Table 3 were compared with the ice tracings in Fig. 6a. This comparison revealed that except for the mass measurements, the quantitative changes tracked the qualitative observations quite well. Likewise THICK values from Table 4 were also compared with the ice tracings in Fig. 6b, and similar results were found.

For some unexplained reason the change in mass was greater for the LWC increase than for the LWC decrease. A review of the mass change from similar conditions at 130 knots, showed that the mass changes were approximately the same for an increase and decrease in LWC. Since the mass change associated with the LWC increase in Tables 3 and 4 appeared to be rather large, we suspected there might be a problem with the reported LWC for that condition. Therefore, we plan to run an icing blade at the condition in question to verify the actual LWC. 
There was also an apparent issue with the THICK calculated value of lower horn thickness for run 29 in Table 4. This value of -0.17 agreed with the general trend for the lower horn thickness to decrease with decreasing LWC. However, the actual value does not compare well with the observed change in Fig. $6 \mathrm{~b}$, where the lower horn peak for run 29 just about overlays the peak for run 28 (which was one of the nominal condition runs). Based on this observation the change in lower ice horn thickness would be negligible.

The reason for the apparent discrepancy between the observed change in lower horn thickness in Fig. 6b, and the calculated value of -0.017 in Table 4 , is that nominal values in Table 4 were calculated using the average value of lower horn thickness from runs 27 and 28. If we had plotted an ice shape that represented the average of runs 27 and run 28 , the calculated change would agree.

Though this appears to be a rather insignificant issue, this apparent discrepancy illustrates the importance of having an accurate nominal or reference value to compare quantitative ice feature changes against. Therefore, it would be desirable to use THICK to determine the nominal ice shape attribute values from more than two repeat runs.

\section{Effect of Varying MVD}

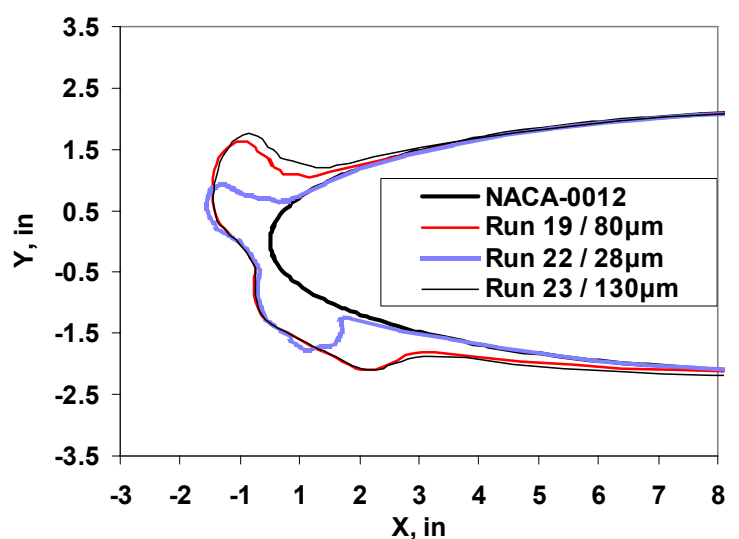

a) $\eta=0.3, V=180$ knots, $\mathrm{Ts}=15.5^{\circ} \mathrm{F}$, $\mathrm{LWC}=0.6 \mathrm{~g} / \mathrm{m}^{3}, \quad \mathrm{AOA}=2.5^{\circ}$

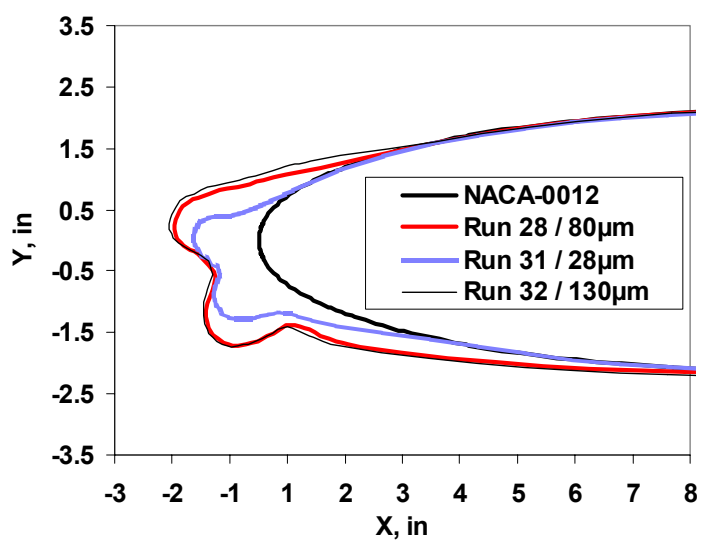

b) $\eta=0.7, \mathrm{~V}=180$ knots, $\mathrm{Ts}=-0.5^{\circ} \mathrm{F}$ $\mathrm{LWC}=0.6 \mathrm{~g} / \mathrm{m}^{3}, \mathrm{AOA}=2.5^{\circ}$

Figure 7. LEWICE predictions showing the effect of MVD variation on ice shape.

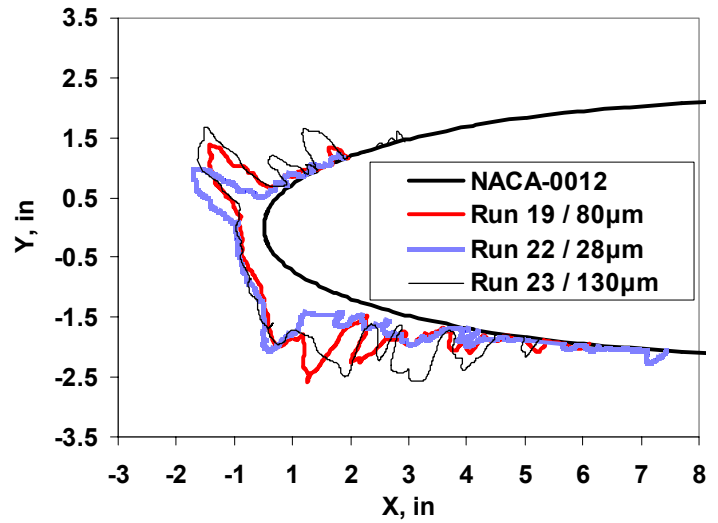

a) $\eta=0.3, V=180$ knots, $\mathrm{Ts}=15.5^{\circ} \mathrm{F}$, $\mathrm{LWC}=0.6 \mathrm{~g} / \mathrm{m}^{3}, \mathrm{AOA}=2.5^{\circ}$

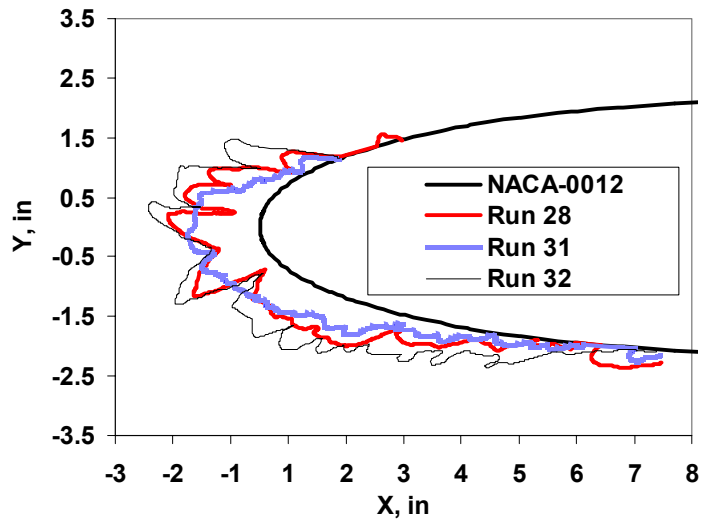

b) $\eta=0.7, \mathrm{~V}=180 \mathrm{knots}, \mathrm{Ts}=-0.5^{\circ} \mathrm{F}$ $\mathrm{LWC}=0.6 \mathrm{~g} / \mathrm{m}^{3}, \mathrm{AOA}=2.5^{\circ}$

Figure 8. Change in ice shape tracings due to MVD variation at $\eta=0.3$ and 0.7 


\section{Computational Trend Prediction}

The effect of MVD variations on ice shape features was evaluated at two freezing fractions of $0.3 \& 0.7$. To get a sense of how ice shape features might change as a result of MVD variations, LEWICE 2.0 was run with the appropriate input conditions from Table 1. The predicted ice shapes for a 180 knot airspeed are shown in Fig. 7.

Figure 7 illustrates the effect of MVD variation on predicted ice shapes for MVD variations of $+/-50 \mu \mathrm{m}$ about a nominal condition of $80 \mu \mathrm{m}$. The effect of freezing fraction on ice shape feature changes can be seen by comparing Fig. $7 \mathrm{a}$ where $\eta=0.3$, with Fig. $7 \mathrm{~b}$ where $\eta=0.7$. Some qualitative observations can be made about expected ice shape changes based on Fig. 7.

For a freezing fraction of 0.3 , it appears as if:

- There is a relatively flat area of the main ice shape about the stagnation region which remains approximately the same regardless of MVD.

- As MVD is increased the upper horns grow larger, and rotate aft (decrease in THICK horn angle).

- The main ice shape extends further aft on the lower surface as the MVD is increased.

- The mass and area of the main ice shape increase as MVD is increased.

- Generally speaking, there is a much smaller change in the ice shape features for an increase in MVD to $130 \mu \mathrm{m}$ relative to the nominal test condition of $80 \mu \mathrm{m}$, than for a decrease in MVD to $28 \mu \mathrm{m}$.

For a freezing fraction of 0.7 , it appears as if:

- Ice horn thickness increases as MVD increases.

- Ice horn angles don't appear to change much.

- There is more ice aft of the main ice shape on both surfaces as MVD is increased.

- As with the $\eta=0.3$ observations, there is a much smaller change in the ice shape features for an increase in MVD to $130 \mu \mathrm{m}$ relative to the nominal test condition of $80 \mu \mathrm{m}$, than for a decrease in MVD to $28 \mu \mathrm{m}$.

\section{Qualitative Assessment Of Actual Ice Shapes}

Figure 8 illustrates the effect of MVD variation on actual ice shapes for MVD variations of $+/-50 \mu \mathrm{m}$ about a nominal condition of $80 \mu \mathrm{m}$. The effect of freezing fraction on ice shape feature changes can be seen by comparing Fig. $8 \mathrm{a}$ where $\eta=0.3$, with Fig. $8 \mathrm{~b}$ where $\eta=0.7$.

The ice shape tracings in Figs. $8 \mathrm{a}$ and $8 \mathrm{~b}$ exhibited similar trends to what was predicted by LEWICE. However, there were some differences between the actual and predicted ice shapes, and these are listed below.

For a freezing fraction of 0.3 :

- The thickness of the flat area of the main ice shape remained about constant (regardless of MVD) near the stagnation line, but the thickness began to change as a function of MVD as you moved toward the lower surface.

- The appearance of large glaze feathers became more prominent aft of the main ice shape as MVD was increased

- As MVD was increased, the lower surface horns became thicker, and appeared to rotate aft. Unlike the LEWICE predictions, there seemed to be an equally significant change in lower horn thickness for a decrease in MVD, when comparing the change observed for an increase in MVD.

- The upper icing limit appeared to move aft on the upper surface for the $130 \mu \mathrm{m}$ run.

- The lower icing limit appeared to move forward on the lower surface with increased MVD

For a freezing fraction of 0.7 :

- In general, the observed trends seemed to follow the LEWICE prediction trends.

- As MVD was increased the feathers on the main ice shape became more clearly defined.

- The icing limit for the $130 \mu \mathrm{m}$ condition extended further aft on the upper surface than for the $28 \mu \mathrm{m}$, or $80 \mu \mathrm{m}$

Based on the above qualitative assessment, it can be said that a $+/-50 \mu \mathrm{m}$ variation in MVD produced visually observable changes in ice shape features, and that the freezing fraction affected the degree to which these feature changes were manifested.

\section{Quantitative Assessment of Actual Ice Shapes}

Given the qualitative assessment above, it was next desired to quantitatively evaluate changes in ice shape features due to variations in MVD. The THICK program was used to quantify ice shape features and the change in these features for an MVD variation of $+/-50 \mu \mathrm{m}$. Tables 5 and 6 contain the results of the THICK analysis for $\eta=$ 0.3 and $\eta=0.7$, respectively. 
Table 5. Thick Calculations For Ice Shape Changes Due To MVD Variation At $\eta=0.3$

\begin{tabular}{|c|c|c|c|c|c|c|c|c|c|c|c|c|}
\hline Description & Run & $\eta$ & $\begin{array}{c}\mathrm{V} \\
\text { (knots) }\end{array}$ & $\begin{array}{l}\text { MVD, } \\
(\mu \mathrm{m})\end{array}$ & $\begin{array}{l}\text { Lower } \\
\text { Icing } \\
\text { Limit } \\
\text { (inches) }\end{array}$ & $\begin{array}{l}\text { Upper } \\
\text { Icing } \\
\text { Limit } \\
\text { (inches) }\end{array}$ & $\begin{array}{c}\text { Lower } \\
\text { Horn } \\
\text { Thickness } \\
\text { (inches) }\end{array}$ & $\begin{array}{c}\text { Upper } \\
\text { Horn } \\
\text { Thickness } \\
\text { (inches) }\end{array}$ & $\begin{array}{c}\text { Area } \\
\left(\text { inch }^{2}\right)\end{array}$ & $\begin{array}{l}\text { Lower } \\
\text { Horn } \\
\text { Angle } \\
\text { (deg) }\end{array}$ & $\begin{array}{l}\text { Upper } \\
\text { Horn } \\
\text { Angle } \\
\text { (deg) }\end{array}$ & $\begin{array}{c}\text { Mass } \\
(\mathrm{gm})\end{array}$ \\
\hline \multirow{3}{*}{$\begin{array}{l}\text { THICK } \\
\text { Values }\end{array}$} & 22 & & & 28 & -7.63 & 1.92 & 1.35 & 1.46 & 3.32 & 272.0 & 141.0 & 611.2 \\
\hline & Nominal & 0.3 & 180 & 80 & -6.09 & 1.91 & 1.48 & 1.48 & 4.08 & 287.4 & 125.0 & 773.9 \\
\hline & 23 & & & 130 & -5.42 & 3.01 & 1.26 & 1.72 & 5.18 & 299.2 & 121.2 & 844.8 \\
\hline \multirow{3}{*}{$\begin{array}{c}\text { Delta } \\
\text { WRT } \\
\text { Nominal } \\
\end{array}$} & 22 & & & -52 & -1.55 & 0.01 & -0.13 & -0.02 & -0.76 & -15.4 & 16.0 & -162.7 \\
\hline & Nominal & 0.3 & 180 & 0 & 0.00 & 0.00 & 0.00 & 0.00 & 0.00 & 0.0 & 0.0 & 0.0 \\
\hline & 23 & & & 50 & 0.67 & 1.10 & -0.22 & 0.24 & 1.09 & 11.8 & -3.8 & 70.9 \\
\hline Nominal & Runs 18\&19 & & & Std Dev & 0.31 & 0.12 & 0.12 & 0.06 & 0.17 & 1.6 & 1.6 & 14.6 \\
\hline Condition & Runs $18 \& 19$ & & & Average & -6.09 & 1.91 & 1.48 & 1.48 & 4.08 & 287.4 & 125.0 & 773.9 \\
\hline
\end{tabular}

Table 6 Thick Calculations For Ice Shape Changes Due To MVD Variation At $\eta=0.7$

\begin{tabular}{|c|c|c|c|c|c|c|c|c|c|c|c|c|}
\hline Description & Run & $\eta$ & $\begin{array}{c}\mathrm{V} \\
\text { (knots) }\end{array}$ & $\begin{array}{l}\text { MVD, } \\
(\mu \mathrm{m})\end{array}$ & $\begin{array}{c}\text { Lower } \\
\text { Icing } \\
\text { Limit } \\
\text { (inches) } \\
\end{array}$ & $\begin{array}{c}\text { Upper } \\
\text { Icing } \\
\text { Limit } \\
\text { (inches) } \\
\end{array}$ & $\begin{array}{c}\text { Lower } \\
\text { Horn } \\
\text { Thickness } \\
\text { (inches) }\end{array}$ & $\begin{array}{c}\text { Upper } \\
\text { Horn } \\
\text { Thickness } \\
\text { (inches) }\end{array}$ & $\begin{array}{c}\text { Area } \\
\left(\text { inch }^{2}\right) \\
\end{array}$ & $\begin{array}{c}\text { Lower } \\
\text { Horn } \\
\text { Angle } \\
\text { (deg) } \\
\end{array}$ & $\begin{array}{l}\text { Upper } \\
\text { Horn } \\
\text { Angle } \\
\text { (deg) }\end{array}$ & $\begin{array}{c}\text { Mass } \\
(\mathrm{gm})\end{array}$ \\
\hline \multirow{3}{*}{$\begin{array}{l}\text { THICK } \\
\text { Values }\end{array}$} & 31 & & & 28 & -7.67 & 1.92 & 1.16 & 1.25 & 3.96 & 215.1 & 186.6 & 684.1 \\
\hline & Nominal & 0.7 & 180 & 80 & -7.69 & 3.05 & 1.55 & 1.69 & 5.61 & 225.3 & 172.3 & 1011.7 \\
\hline & 32 & & & 130 & -7.58 & 1.95 & 1.82 & 1.95 & 7.78 & 221.4 & 169.7 & 1275.4 \\
\hline \multirow{3}{*}{$\begin{array}{c}\text { Delta } \\
\text { WRT } \\
\text { Nominal }\end{array}$} & 31 & & & -52 & 0.02 & -1.13 & -0.39 & -0.43 & -1.65 & -10.2 & 14.3 & -327.6 \\
\hline & Nominal & 0.7 & 180 & 0 & 0.00 & 0.00 & 0.00 & 0.00 & 0.00 & 0.0 & 0.0 & 0.0 \\
\hline & 32 & & & 50 & 0.11 & -1.10 & 0.27 & 0.26 & 2.17 & -3.9 & -2.6 & 263.7 \\
\hline Nominal & Runs 27\&28 & & & Std Dev & 0.03 & 0.02 & 0.11 & 0.13 & 0.15 & 0.2 & 0.3 & 3.7 \\
\hline Condition & Runs 27\&28 & & & Average & -7.69 & 3.05 & 1.55 & 1.69 & 5.61 & 225.3 & 172.3 & 1011.7 \\
\hline
\end{tabular}

THICK values from Table 5 were compared with the ice tracings in Fig. 8a. Ice shape feature changes which exceeded the standard deviation have been highlighted. This comparison revealed that the quantitative changes tracked the qualitative observations quite well.

There were a few attribute changes that looked questionable, however. These were: (1) the upper icing limit for run 23, and (2) the apparent forward movement of the lower icing limits with increased drop size. After reviewing photographs, the run 23 upper icing limit change was due to a small surface feature that accreted on a surface irregularity, and probably should not have been traced. Thus it can be considered to be an ice tracing artifact, and not real.

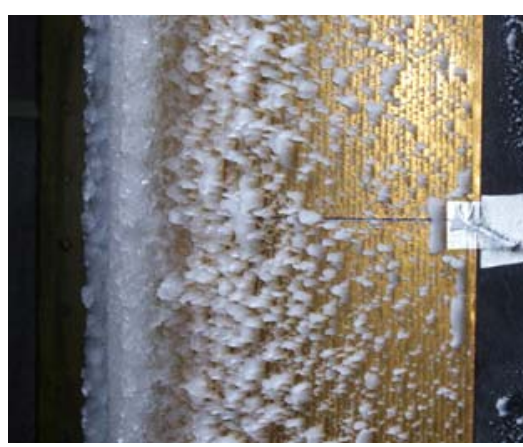

a) $\mathrm{MVD}=28 \mu \mathrm{m}$, run 22

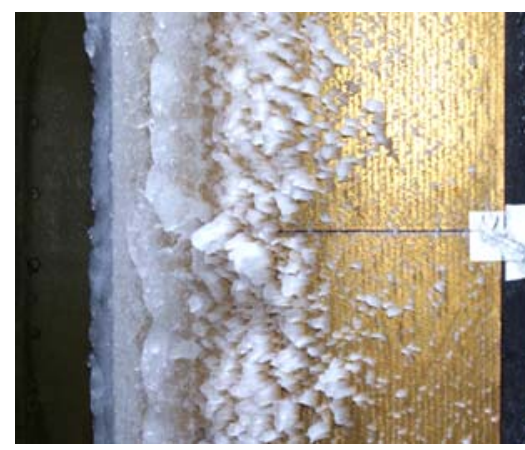

b) $\mathrm{MVD}=80 \mu \mathrm{m}$, run 19

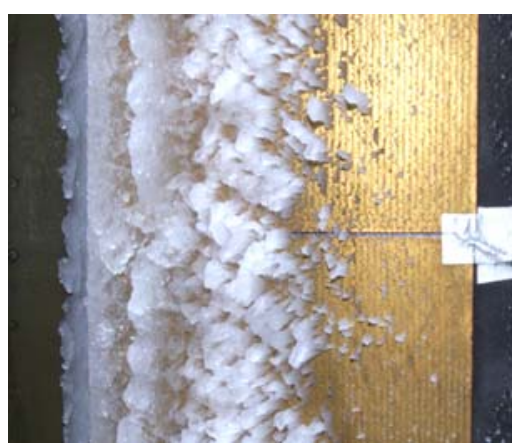

c) $\mathrm{MVD}=130 \mu \mathrm{m}$, Run 23

Figure 9. Comparison of lower surface icing limits for different MVD (note: LE is toward left side of picture). 
Interestingly enough, the apparent forward movement of the lower surface icing limit was actually real. Figure 9 illustrates this trend with 3 photos of the lower surface.

THICK values from Table 6 were compared with the ice tracings in Fig. 8b, and it was found those quantitative changes again tracked the qualitative observations. The calculated value for upper icing limit change had a negative value for the low MVD condition (run 31) and also for the high MVD condition (run 32). This looked strange, so photos of the upper surface were reviewed for these test runs, and it was determined that this was an ice tracing artifact, and thus not a real change.

\section{Effect of Varying Temperature}

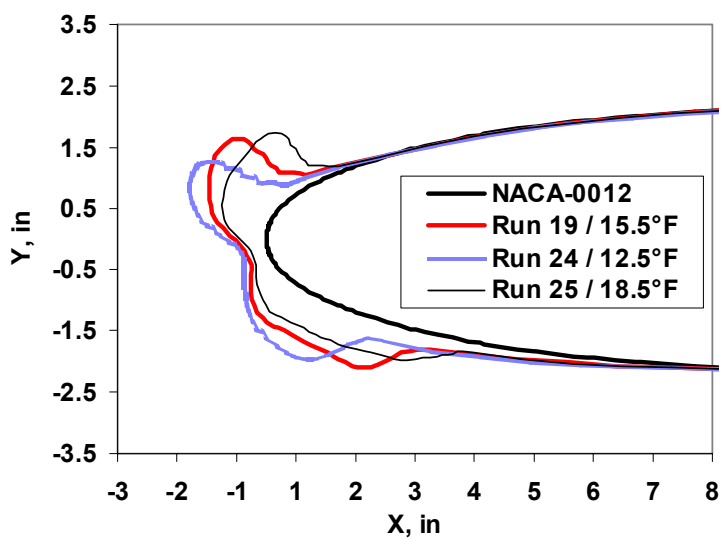

a) $\eta=0.3, \mathrm{~V}=180 \mathrm{knots}, \mathrm{LWC}=0.6 \mathrm{gm} / \mathrm{m}^{3}$, $\mathrm{MVD}=\mathbf{8 0 \mu \mathrm { m }}, \mathrm{AOA}=\mathbf{2 . 5 ^ { \circ }}$

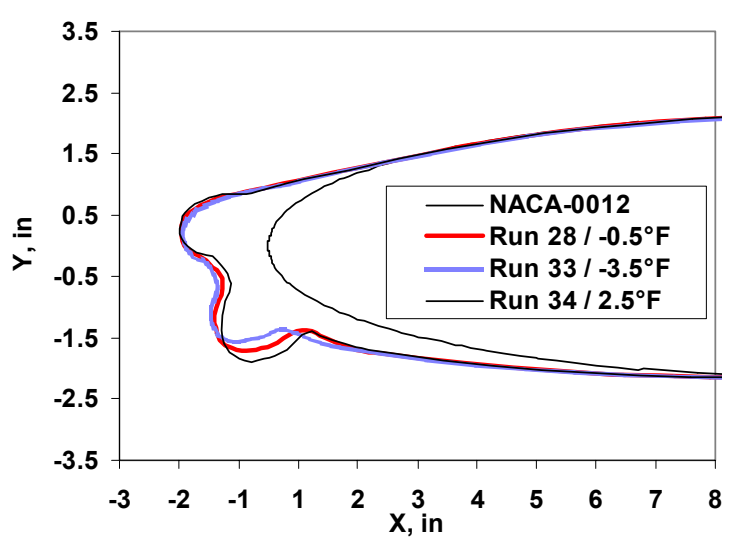

b) $\eta=0.7, V=180$ knots, $L W C=0.6 \mathrm{gm} / \mathrm{m}^{3}$, $\mathrm{MVD}=80 \mu \mathrm{m}, \mathrm{AOA}=2.5^{\circ}$

Figure 10. LEWICE predictions showing the effect of temperature variations on ice shape.

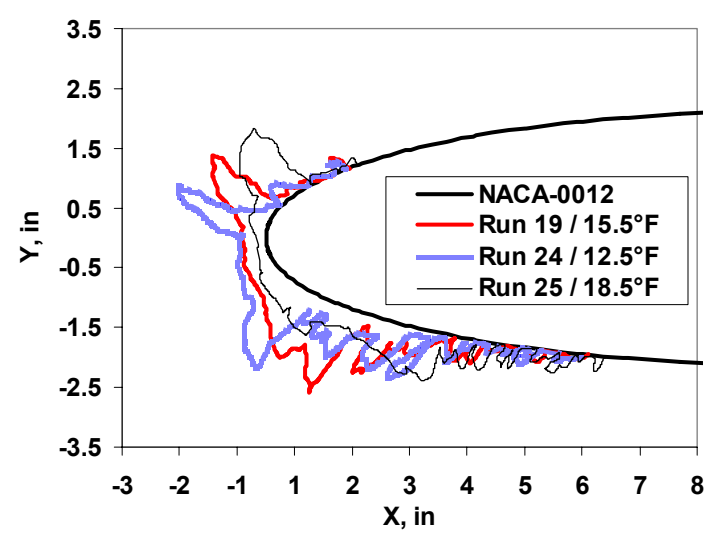

a) $\eta=0.3, V=180$ knots, $L W C=0.6 \mathrm{gm} / \mathrm{m}^{3}$, $\mathrm{MVD}=80 \mu \mathrm{m}, \mathrm{AOA}=2.5^{\circ}$

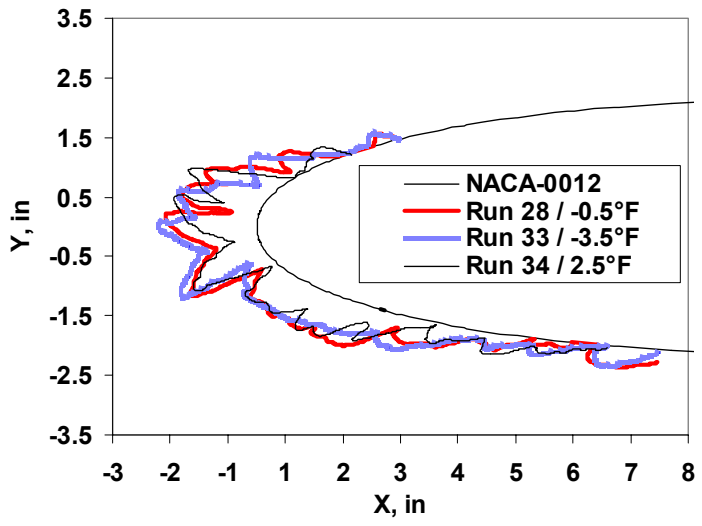

b) $\eta=0.7, \mathrm{~V}=180$ knots, $\mathrm{LWC}=0.6 \mathrm{gm} / \mathrm{m}^{3}$, $\mathrm{MVD}=80 \mu \mathrm{m}, \mathrm{AOA}=2.5^{\circ}$

Figure 11. Change in ice shape tracings due to temperature variation at $\boldsymbol{\eta}=0.3$ and 0.7 


\section{Computational Trend Prediction}

The effect of temperature variations on ice shapes was evaluated at two freezing fractions of 0.3 and 0.7 . To get a sense of how ice shape features might change as a result of temperature variations, LEWICE 2.0 was run with the appropriate input conditions from Table 1. The predicted ice shapes for a 180 knot airspeed are shown in Fig. 10.

Figure 10 illustrates the effect of MVD variation on predicted ice shapes for MVD variations of $+/-3{ }^{\circ} \mathrm{F}$ about nominal conditions of $15.5^{\circ} \mathrm{F}$ at $\eta=0.3$, and $-0.5^{\circ} \mathrm{F}$ at $\eta=0.7$. The effect of freezing fraction on ice shape feature changes can be seen by comparing Fig. $10 \mathrm{a}$ where $\eta=0.3$, with Fig. $10 \mathrm{~b}$ where $\eta=0.7$. Some qualitative observations can be made about expected ice shape changes based on Fig. 10.

For a freezing fraction of 0.3 , it appears as if:

- The upper ice horns rotate aft toward the upper surface as the temperature is increased

- The mass in the main ice shape is re-distributed further aft on the lower surface, as the temperature increases.

For a freezing fraction of 0.7 , it appears as if:

- The upper ice horn thickness and angles remain the same with increasing temperature.

- The lower ice horn angle rotates aft toward the lower surface with increasing temperature.

The LEWICE results suggest that the $+/-3^{\circ} \mathrm{F}$ variation should yield discernible changes in ice shape features, and that the feature changes appear to be affected by the freezing fraction.

\section{Qualitative Assessment Of Actual Ice Shapes}

Figure 11 illustrates the effect of temperature variation on actual ice shapes for temperature variations of $+/-3{ }^{\circ} \mathrm{F}$ about nominal conditions of $15.5^{\circ} \mathrm{F}$ at $\eta=0.3$, and $-0.5^{\circ} \mathrm{F}$ at $\eta=0.7$. The effect of freezing fraction on ice shape feature changes can be seen by comparing Fig. $11 \mathrm{a}$ where $\eta=0.3$, with Fig. $11 \mathrm{~b}$ where $\eta=0.7$.

The ice shape tracings in Figs. 11a and 11b exhibited similar trends to what was predicted by LEWICE. However, there were some differences between the actual and predicted ice shapes, and these are listed below.

For a freezing fraction of 0.3 :

- The upper ice horns showed a very significant rotation aft toward the upper surface (decreasing horn angle).

- The lower horn thickness for the warmest temperature case seems to have decreased significantly, with the re-distribution of mass on the lower surface of the airfoil.

- The icing limits moved very slightly aft on both the upper and lower surfaces

For a freezing fraction of 0.7 :

- In general, the horn thickness appears to have decreased with increasing temperature

- The upper horn angle appears to have rotated slightly aft toward the upper surface with increasing temperature.

- The icing limits appear to have moved slightly forward toward the leading edge on both surfaces.

Based on the above qualitative assessment, it can be said that a $+/-3^{\circ} \mathrm{F}$ variation in temperature produced visually observable changes in ice shape features, and that the freezing fraction affected the degree to which these feature changes were manifested.

\section{Quantitative Assessment of Actual Ice Shapes}

Given the qualitative assessment above, it was next desired to quantitatively evaluate changes in ice shape features due to these variations in temperature. The THICK program was used to quantify ice shape features and the change in these features for a $+/-3^{\circ} \mathrm{F}$ temperature change. Tables 7 and 8 contain the results of the THICK analysis for $\eta=0.3$ and $\eta=0.7$, respectively.

THICK values from Table 7 were compared with the ice tracings in Fig. 11a. Ice shape feature changes which exceeded the standard deviation have been highlighted. This comparison revealed that quantitative changes agreed well with qualitative observations about ice feature change due to temperature variation.

There were however several ice shape feature changes in Table 7 that are worthy of mention. One of those was the negligible mass change with temperature variation. Since the icing spray condition remained the same for each test run in Table 7, it was somewhat expected that there would be a small variation in mass. The mass change results in Table 7 were only slightly larger than the standard deviation associated with the nominal condition. This result also implies that if the mass isn't changing with temperature, then any ice feature changes would be due to a re-distribution of mass. This rationale agrees with the qualitative observations of ice feature changes noted in Fig.11a, which indicated the main ice shape mass seemed to shift progressively more toward the lower surface with increasing temperature. 
It is interesting to note that the ice horn angle changes in Table 7, were greater than any horn angle changes due to LWC or MVD variations discussed so far. They were about twice the maximum value noted for ice horn angle changes due to LWC or MVD variations.

Table 7. Thick Calculations For Ice Shape Changes Due To Temperature Variation At $\boldsymbol{\eta}=0.3$

\begin{tabular}{|c|c|c|c|c|c|c|c|c|c|c|c|c|}
\hline Description & Run & $\eta$ & $\begin{array}{c}\mathrm{V} \\
\text { (knots) }\end{array}$ & $\mathrm{Ts},\left({ }^{\circ} \mathrm{F}\right)$ & $\begin{array}{l}\text { Lower } \\
\text { Icing } \\
\text { Limit } \\
\text { (inches) }\end{array}$ & $\begin{array}{c}\text { Upper } \\
\text { Icing } \\
\text { Limit } \\
\text { (inches) }\end{array}$ & $\begin{array}{c}\text { Lower } \\
\text { Horn } \\
\text { Thickness } \\
\text { (inches) }\end{array}$ & $\begin{array}{c}\text { Upper } \\
\text { Horn } \\
\text { Thickness } \\
\text { (inches) }\end{array}$ & $\begin{array}{c}\text { Area } \\
\left(\text { inch }^{2}\right)\end{array}$ & $\begin{array}{c}\text { Lower } \\
\text { Horn } \\
\text { Angle } \\
\text { (deg) }\end{array}$ & $\begin{array}{l}\text { Upper } \\
\text { Horn } \\
\text { Angle } \\
\text { (deg) }\end{array}$ & $\begin{array}{l}\text { Mass } \\
(\mathrm{gm})\end{array}$ \\
\hline \multirow{3}{*}{$\begin{array}{l}\text { THICK } \\
\text { Values }\end{array}$} & 24 & & & 12.5 & -6.18 & 1.93 & 1.58 & 1.69 & 3.82 & 265.1 & 149.9 & 785.1 \\
\hline & Nominal & 0.3 & 180 & 15.5 & -6.09 & 1.91 & 1.48 & 1.48 & 4.08 & 287.4 & 125.0 & 773.9 \\
\hline & 25 & & & 18.5 & -6.61 & 2.15 & 0.83 & 1.31 & 3.69 & 318.8 & 96.4 & 755.1 \\
\hline \multirow{3}{*}{$\begin{array}{c}\text { Delta } \\
\text { WRT } \\
\text { Nominal }\end{array}$} & 24 & & & -3.0 & -0.09 & 0.02 & 0.10 & 0.21 & -0.26 & -22.3 & 24.9 & 11.3 \\
\hline & Nominal & 0.3 & 180 & 0.0 & 0.00 & 0.00 & 0.00 & 0.00 & 0.00 & 0.0 & 0.0 & 0.0 \\
\hline & 25 & & & 3.0 & -0.53 & 0.23 & -0.65 & -0.17 & -0.39 & 31.4 & -28.6 & -18.8 \\
\hline Nominal & Runs $18 \& 19$ & & & Std Dev & 0.31 & 0.12 & 0.12 & 0.06 & 0.17 & 1.6 & 1.6 & 14.6 \\
\hline Condition & Runs $18 \& 19$ & & & Average & -6.09 & 1.91 & 1.48 & 1.48 & 4.08 & 287.4 & 125.0 & 773.9 \\
\hline
\end{tabular}

Table 8. Thick Calculations For Ice Shape Changes Due To Temperature Variation At $\boldsymbol{\eta}=0.7$

\begin{tabular}{|c|c|c|c|c|c|c|c|c|c|c|c|c|}
\hline Description & Run & $n$ & $\begin{array}{c}\mathrm{V} \\
\text { (knots) }\end{array}$ & $\mathrm{Ts},\left({ }^{\circ} \mathrm{F}\right)$ & $\begin{array}{l}\text { Lower } \\
\text { Icing } \\
\text { Limit } \\
\text { (inches) }\end{array}$ & $\begin{array}{c}\text { Upper } \\
\text { Icing } \\
\text { Limit } \\
\text { (inches) }\end{array}$ & $\begin{array}{c}\text { Lower } \\
\text { Horn } \\
\text { Thickness } \\
\text { (inches) }\end{array}$ & $\begin{array}{c}\text { Upper } \\
\text { Horn } \\
\text { Thickness } \\
\text { (inches) }\end{array}$ & $\begin{array}{c}\text { Area } \\
\left(\text { inch }^{2}\right)\end{array}$ & $\begin{array}{c}\text { Lower } \\
\text { Horn } \\
\text { Angle } \\
\text { (deg) }\end{array}$ & $\begin{array}{l}\text { Upper } \\
\text { Horn } \\
\text { Angle } \\
\text { (deg) }\end{array}$ & $\begin{array}{c}\text { Mass } \\
(\mathrm{gm})\end{array}$ \\
\hline \multirow{3}{*}{$\begin{array}{l}\text { THICK } \\
\text { Values }\end{array}$} & 33 & & & -3.5 & -7.68 & 3.07 & 1.66 & 1.72 & 5.51 & 222.5 & 178.9 & 1099.1 \\
\hline & Nominal & 0.7 & 180 & -0.5 & -7.69 & 3.05 & 1.55 & 1.69 & 5.61 & 225.3 & 172.3 & 1011.7 \\
\hline & 34 & & & 2.5 & -6.80 & 2.20 & 1.39 & 1.49 & 4.41 & 224.0 & 161.6 & 1058.6 \\
\hline \multirow{3}{*}{$\begin{array}{c}\text { Delta } \\
\text { WRT } \\
\text { Nominal }\end{array}$} & 33 & & & -3.0 & 0.01 & 0.02 & 0.10 & 0.03 & -0.11 & -2.8 & 6.6 & 87.4 \\
\hline & Nominal & 0.7 & 180 & 0.0 & 0.00 & 0.00 & 0.00 & 0.00 & 0.00 & 0.0 & 0.0 & 0.0 \\
\hline & 34 & & & 3.0 & 0.89 & -0.85 & -0.17 & -0.20 & -1.20 & -1.3 & -10.8 & 46.9 \\
\hline Nominal & Runs 27\&28 & & & Std Dev & 0.03 & 0.02 & 0.11 & 0.13 & 0.15 & 0.2 & 0.3 & 3.7 \\
\hline Condition & Runs $27 \& 28$ & & & Average & -7.69 & 3.05 & 1.55 & 1.69 & 5.61 & 225.3 & 172.3 & 1011.7 \\
\hline
\end{tabular}

THICK values from Table 8 were compared with the ice tracings in Fig. 11b, and this comparison revealed that quantitative changes agreed with the qualitative observations about ice feature change due to temperature variation. As expected, there was less variation in parameters at this freezing fraction of 0.7 , versus what was observed at $\eta=$ 0.3 in Table 7. Though the mass change was larger than in Table 7, it may still be within experimental accuracy associated with our mass measurement which had approximately 4 percent error associated with it. This accuracy estimate is based on cumulative experience from previous experiments where the authors have acquired ice shape mass measurements. Thus the value of 46.9 grams for a mass change would constitute about 4 percent of the ice mass acquired at the nominal condition $(1011 \mathrm{gm})$. The value of 87.4 grams would constitute about an 8 percent change in ice mass.

\section{Summary of Results}

Qualitative and quantitative results have been presented concerning the variation of LWC, MVD, and temperature and their effect on ice shape features. For the level of parameter variation selected for this study there were clearly discernible changes in ice shape features. But what if we had chosen a smaller level of variation in LWC, MVD, or temperature? How small could that variation be, before we would approach the level where ice shape feature changes would be on the order of the ice shape repeatability? This section will summarize the results from the previous sections in a way that attempts to answer these questions.

Selected THICK data from the previous sections were subjected to an additional processing step. The icing limit data were excluded from this process because they were deemed to have too much variability due to possible errors inherent in the tracing process. Since errors in icing limits would also translate into errors in the calculated iced area, the iced area was excluded from this processing step.

The process involved first normalizing the THICK calculated ice shape feature change. This was accomplished by dividing the calculated change value by the standard deviation for that ice feature. Next the parameter variation 
was then divided by this normalized change value computed in the previous step. The end result was an indication of the parameter variation required to produce a standard deviation of change in the ice feature of interest.

As an example: if the change in the upper icing horn were 16 degrees, and the standard deviation for this feature was 1.6, then the normalized change would be 10 . If this change was caused by a $-52 \mu \mathrm{m}$ variation in MVD (relative to the nominal condition), then the value of variation $(-52)$ would be divided by the normalized change (10), to yield a result of -5.20 . The interpretation of this result is that a decrease of 5.2 microns in drop size would produce the level of change in the ice feature (corresponding to a standard deviation). This processing step assumes that the change in ice feature is linear between the nominal condition and the variant condition. While the icing process is not linear, this may be acceptable as a first order approximation. The results from this process are summarized in Table 9 for variations in LWC, MVD, and temperature.

Table 9 Parameter Variation to Produce Standard Deviation of Change in THICK Calculation

\begin{tabular}{|c|c|c|c|c|c|c|c|c|}
\hline $\begin{array}{l}\text { Parameter } \\
\text { Being Varied }\end{array}$ & Description & Run & $\begin{array}{c}\text { Parameter } \\
\text { Change }\end{array}$ & $\begin{array}{c}\text { Lower } \\
\text { Horn } \\
\text { Thickness } \\
\text { (inches) }\end{array}$ & $\begin{array}{c}\text { Upper } \\
\text { Horn } \\
\text { Thickness } \\
\text { (inches) }\end{array}$ & $\begin{array}{l}\text { Lower Horn } \\
\text { Angle (deg) }\end{array}$ & $\begin{array}{l}\text { Upper } \\
\text { Horn Angle } \\
\text { (deg) }\end{array}$ & Mass (gm) \\
\hline \multirow{5}{*}{$\begin{array}{c}\text { LWC } \\
\left(\mathrm{g} / \mathrm{m}^{3}\right) \\
\eta=0.3 \\
\mathrm{~V}=180 \text { knots }\end{array}$} & Std Dev & & & 0.12 & 0.06 & 1.6 & 1.6 & 14.6 \\
\hline & \multirow{2}{*}{$\begin{array}{c}\text { Change in } \\
\text { value }\end{array}$} & 20 & -0.10 & -0.14 & -0.23 & -7.7 & 6.6 & -124.3 \\
\hline & & 21 & 0.10 & 0.01 & 0.14 & 11.5 & -5.4 & 242.7 \\
\hline & $\mathrm{g} / \mathrm{m}^{3}$ per Std & 20 & & 0.084 & 0.025 & 0.020 & -0.024 & 0.012 \\
\hline & Dev & 21 & & 1.268 & 0.042 & 0.014 & -0.029 & 0.006 \\
\hline \multirow{5}{*}{$\begin{array}{c}\text { LWC } \\
\left(\mathrm{g} / \mathrm{m}^{3}\right) \\
\eta=0.7\end{array}$} & Std Dev & & & 0.11 & 0.13 & 0.2 & 0.3 & 3.7 \\
\hline & \multirow{2}{*}{$\begin{array}{c}\text { Change in } \\
\text { value }\end{array}$} & 29 & -0.10 & -0.17 & -0.29 & 2.7 & 6.6 & -192.8 \\
\hline & & 30 & 0.10 & 0.12 & 0.18 & -5.1 & -1.3 & 412.6 \\
\hline & \multirow{2}{*}{$\begin{array}{c}\mathrm{g} / \mathrm{m}^{3} \text { per Std } \\
\text { Dev }\end{array}$} & 29 & & 0.062 & 0.044 & -0.007 & -0.004 & 0.002 \\
\hline & & 30 & & 0.088 & 0.071 & -0.004 & -0.022 & 0.001 \\
\hline \multirow{5}{*}{$\begin{array}{c}\text { MVD } \\
(\mu \mathrm{m}) \\
\eta=0.3 \\
\mathrm{~V}=180 \text { knots }\end{array}$} & Std Dev & & & 0.12 & 0.06 & 1.6 & 1.6 & 14.6 \\
\hline & \multirow{2}{*}{$\begin{array}{c}\text { Change in } \\
\text { value }\end{array}$} & 22 & -52 & -0.13 & -0.02 & -15.4 & 16.0 & -162.7 \\
\hline & & 23 & 50 & -0.22 & 0.24 & 11.8 & -3.8 & 70.9 \\
\hline & \multirow{2}{*}{$\begin{array}{c}\mu \mathrm{m} \text { per Std } \\
\text { Dev }\end{array}$} & 22 & & 46.7 & 132.7 & 5.3 & -5.2 & 4.7 \\
\hline & & 23 & & -26.7 & 12.2 & 6.6 & -21.1 & 10.3 \\
\hline \multirow{5}{*}{$\begin{array}{c}\text { MVD } \\
(\mu \mathrm{m}) \\
\eta=0.7 \\
V=180 \text { knots } \\
\end{array}$} & Std Dev & & & 0.11 & 0.13 & 0.2 & 0.3 & 3.7 \\
\hline & Change in & 31 & -52 & -0.39 & -0.43 & -10.2 & 14.3 & -327.6 \\
\hline & value & 32 & 50 & 0.27 & 0.26 & -3.9 & -2.6 & 263.7 \\
\hline & $\mu \mathrm{m}$ per Std & 31 & & 13.9 & 15.6 & 1.0 & -1.0 & 0.6 \\
\hline & Dev & 32 & & 19.5 & 24.5 & -2.5 & -5.5 & 0.7 \\
\hline \multirow{5}{*}{$\begin{array}{c}\text { Ts } \\
\left({ }^{\circ} \mathrm{F}\right) \\
\eta=0.3 \\
V=180 \text { knots }\end{array}$} & Std Dev & & & 0.12 & 0.06 & 1.6 & 1.6 & 14.6 \\
\hline & \multirow{2}{*}{$\begin{array}{c}\text { Change in } \\
\text { value }\end{array}$} & 24 & -3.0 & 0.10 & 0.21 & -22.3 & 24.9 & 11.3 \\
\hline & & 25 & 3.0 & -0.65 & -0.17 & 31.4 & -28.6 & -18.8 \\
\hline & ${ }^{\circ} \mathrm{F}$ per Std & 24 & & -3.4 & -0.8 & 0.2 & -0.2 & -3.9 \\
\hline & Dev & 25 & & -0.5 & -1.1 & 0.1 & -0.2 & -2.3 \\
\hline \multirow{5}{*}{$\begin{array}{c}\text { Ts } \\
\left({ }^{\circ} \mathrm{F}\right) \\
\eta=0.7 \\
V=180 \text { knots }\end{array}$} & Std Dev & & & 0.11 & 0.13 & 0.2 & 0.3 & 3.7 \\
\hline & \multirow{2}{*}{$\begin{array}{l}\text { Change in } \\
\text { value }\end{array}$} & 33 & -3.0 & 0.10 & 0.03 & -2.8 & 6.6 & 87.4 \\
\hline & & 34 & 3.0 & -0.17 & -0.20 & -1.3 & -10.8 & 46.9 \\
\hline & ${ }^{\circ} \mathrm{F}$ per Std & 33 & & -3.1 & -13.1 & 0.2 & -0.1 & -0.1 \\
\hline & Dev & 34 & & -1.9 & -2.0 & -0.4 & -0.1 & 0.2 \\
\hline
\end{tabular}

The rows in Table 9 labeled $" \mathrm{~g} / \mathrm{m}^{3}$ per Std Dev" contain the results of the processed THICK ice feature calculations for LWC variation. The values in these rows represent the amount of change in LWC required to produce a change in the THICK ice shape feature equal to the measured standard deviation of that feature. Values significantly less than the $0.1 \mathrm{~g} / \mathrm{m}^{3}$ LWC variation of this study would be very desirable, and could imply that smaller LWC content variations would yield discernable quantitative changes in these ice features. This same rationale applies to the MVD, and temperature variation data in this table. 
Some of the calculated values have been highlighted if they had an absolute value less than 25 percent of the parameter variations selected for this study $\left(0.1 \mathrm{~g} / \mathrm{m}^{3}, 50 \mathrm{um}\right.$, and $\left.3.0^{\circ} \mathrm{F}\right)$. This was intended to identify potential ice features which would be sensitive enough to smaller parameter changes. The ice horn angles and mass seem to be two ice shape features which would be sensitive to smaller LWC, MVD, or temperature variations in this study.

Table 9 represents a preliminary attempt to relate the sensitivity of quantitative ice shape features to variations in icing parameters like LWC, MVD, or temperature. There are recognized limitations in what can be ultimately concluded from the data presented in this report, but the results suggest quantitative measurements of ice shape features have potential for aiding in the definition of requirements, particularly for SLD ice protection codes.

\section{Conclusions}

A sensitivity study was conducted to evaluate the effect of LWC, MVD, and temperature changes on ice shape features. This study employed the following parameter variations: $\mathrm{LWC}=+/-0.1 \mathrm{~g} / \mathrm{m}^{3}, \mathrm{MVD}=+/-50 \mu \mathrm{m}$, and temperature $=+/-3{ }^{\circ} \mathrm{F}$. Ice shape tracings, and ice shape mass measurements were acquired for each test condition. These data were then qualitatively and quantitatively analyzed.

Preliminary results suggest that smaller parameter variations might produce discernible ice feature changes. These variations were found to be less than $0.1 \mathrm{~g} / \mathrm{m}^{3}$ for $\mathrm{LWC}$, on the order of $10 \mu \mathrm{m}$ for MVD, and less than $1.0^{\circ} \mathrm{F}$ for temperature.

Additional conclusions drawn from this investigation are listed below.

(1) The level of LWC, MVD, and temperature variation used in this study produced changes in ice shape features which were readily discernible using both qualitative and quantitative methods. The data suggest that some ice features like ice horn angle and mass may be sensitive enough to allow smaller LWC, MVD, and temperature variations to be used in future studies, but the study was not conclusive enough to establish the minimum parameter variation that could practically be achieved. The following uncertainties are believed to be factors that will practically limit the smallest achievable parameter variation:

- Uncertainties due to small perturbations in parameters being held constant, but causing an undesired change in the ice shape of a variant parameter (e.g., MVD varied but slight changes occur in LWC, and temperature which are supposedly held constant).

- Uncertainties in icing tunnel spray calibration definition of MVD and LWC values.

- Uncertainties in LWC due to cloud uniformity effects.

(2) Quantitative methods were successfully applied to the evaluation of ice shape features in this study, and were considered to be indispensable to the analysis process. It is believed that the quantitative methods are required to discern subtle changes in ice shape features, and facilitate comparisons over a range of different conditions. The use of quantitative methods removes the subjectivity that is typically associated with qualitative evaluations of ice shape feature changes. The THICK analysis program proved to be a very valuable analysis tool.

(3) A simple method was used to estimate the level of LWC, MVD, and temperature variation associated with the repeatability error in selected THICK calculations (horn thickness, horn angles, and mass). It was found that changes in upper and lower horn angles, and mass seemed to have the greatest sensitivity to MVD, LWC, or temperature variations.

(4) Accounting for the fact that LEWICE does not predict feather growth, there was generally good agreement between the trends in ice shape feature changes predicted by LEWICE, and what was observed from reviewing actual ice shape tracings. It was desired to include a quantitative evaluation of LEWICE predicted ice shapes for the conditions of this study, but that was not possible due to space limitations.

(5) Errors in the ice shape generation and measurement process really need to be carefully controlled. Some suggested improvements to what was employed in this study are listed below:

- Develop a better estimate of the repeatability of the nominal (or reference) conditions using more than two repeat runs.

- The repeatability for the nominal condition was determined, but should probably have been done for variant conditions as well.

- Some guidelines should be established concerning where to stop tracing, as you approach the icing limits

- Develop some methodology to ensure the ice tracing template is properly positioned in the ice tracing cut on the airfoil 
(6) It should be mentioned that the results of this study have limitations associated with only evaluating one airfoil. It is recognized that different airfoil characteristics (geometry, chord, etc) could exhibit differences relative to what has been reported here.

Based on what has been learned from this study, there are a number of recommendations that can be made regarding further work in this area.

- Complete the analysis of LEWICE predicted ice shapes with the THICK program, and compare the predicted ice feature changes with actual changes from this experimental study.

- Assess the potential use of design of experiments principles for use in defining future testing. As part of this assessment, it may also be prudent to try and estimate the overall experimental uncertainty associated with ice feature changes (accounting for uncertainties in tunnel spray calibration, uniformity, ice shape tracing errors, ...etc.)

- Develop some preliminary estimates of the needed resolution in ice feature change measurements, based on iced aerodynamic performance factors. It is envisioned this might be accomplished by reviewing the large body of work that exists on iced aerodynamic performance, and possibly complimented by conducting appropriate CFD investigations. These estimates could then be used to help define the desired level of parameter variations for future sensitivity tests.

- Consider conducting additional sensitivity experiments on other airfoil geometries.

\section{References}

${ }^{1}$ Bond, T., Miller, D., and Potapczuk, M., “Overview Of SLD Engineering Tools Development,” AIAA-2003-0386.

${ }^{2}$ Miller, D., Potapczuk, M., Bond, T., “Update On SLD Engineering Tools Development,” SAE-2003-01-2127.

${ }^{3}$ Cober, S.G., Isaac, G.A., Strapp, J.W., "Characterizations of Aircraft Icing Environments That Include Supercooled Large Drops," Journal of applied Meteorology, Vol. 40, No. 11, November 2001, pp. 1984-2001.

${ }^{4}$ Korolev, A.V., Strapp, J.W., Isaac, G.A., and Nevzorov, A.N., "The Nevzorov Airborne Hot-Wire LWC-TWC Probe: Principle of Operation and Performance Characteristics," Journal of Atmospheric and Oceanic Technology, Vol. 15, No. 6, December 1998, pp. 1495-1509.

${ }^{5}$ Strapp, J.W., Oldenburg, J., Ide, R., Lilie, L., Bacic, S., Vukovic, Z., Oleskiw, M., Miller, D., Emery, E., and Leone, G., "Wind Tunnel Measurements of The Response of Hot-Wire Liquid Water Content Instruments To Large Droplets," Journal of Atmospheric and Oceanic Technology, Vol. 20, No. 6, June 2003, pp. 791-805.

${ }^{6}$ Wright, W., Rutkowski, A., "Validation Report for LEWICE 2.0,” NASA CR-208690, January 1999. 


\begin{tabular}{|c|c|c|c|}
\hline \multicolumn{3}{|c|}{ REPORT DOCUMENTATION PAGE } & $\begin{array}{l}\text { Form Approved } \\
\text { OMB No. 0704-0188 }\end{array}$ \\
\hline \multicolumn{4}{|c|}{ 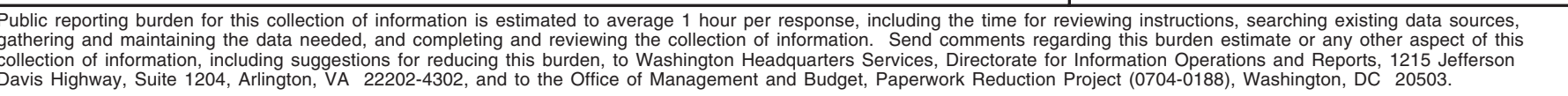 } \\
\hline 1. AGENCY USE ONLY (Leave blank) & $\begin{array}{r}\text { 2. REPORT DATE } \\
\text { March } 2005\end{array}$ & 3.1 & $\begin{array}{l}\text { ID DATES COVERED } \\
\text { echnical Memorandum }\end{array}$ \\
\hline \multicolumn{3}{|c|}{$\begin{array}{l}\text { 4. TITLE AND SUBTITLE } \\
\text { Preliminary Investigation of Ice Shape Sensitivity to Parameter Variations }\end{array}$} & \multirow{2}{*}{$\begin{array}{l}\text { 5. FUNDING NUMBERS } \\
\text { WBS-22-728-41-17 }\end{array}$} \\
\hline \multicolumn{3}{|c|}{$\begin{array}{l}\text { 6. AUTHOR(S) } \\
\text { Dean R. Miller, Mark G. Potapczuk, and Tammy J. Langhals }\end{array}$} & \\
\hline \multicolumn{3}{|c|}{$\begin{array}{l}\text { 7. PERFORMING ORGANIZATION NAME(S) AND ADDRESS(ES) } \\
\text { National Aeronautics and Space Administration } \\
\text { John H. Glenn Research Center at Lewis Field } \\
\text { Cleveland, Ohio } 44135-3191\end{array}$} & $\begin{array}{l}\text { 8. PERFORMING ORGANIZATION } \\
\text { REPORT NUMBER } \\
\text { E-15008 }\end{array}$ \\
\hline \multicolumn{3}{|c|}{$\begin{array}{l}\text { 9. SPONSORING/MONITORING AGENCY NAME(S) AND ADDRESS(ES) } \\
\text { National Aeronautics and Space Administration } \\
\text { Washington, DC 20546-0001 }\end{array}$} & $\begin{array}{l}\text { 10. SPONSORING/MONITORING } \\
\text { AGENCY REPORT NUMBER } \\
\text { NASA TM-2005-213562 } \\
\text { AIAA-2005-0073 }\end{array}$ \\
\hline \multicolumn{4}{|c|}{$\begin{array}{l}\text { 11. SUPPLEMENTARY NOTES } \\
\text { Prepared for the 43rd Aerospace Sciences Meeting and Exhibit sponsored by the American Institute of Aeronautics and } \\
\text { Astronautics, Reno, Nevada, January 10-13, 2005. Dean R. Miller and Mark G. Potapczuk, NASA Glenn Research Center; } \\
\text { Tammy J. Langhals, QSS Group, Inc., 21000 Brookpark Road, Cleveland, Ohio 44135. Responsible person, Dean R. } \\
\text { Miller, organization code RTI, 216-433-5349. }\end{array}$} \\
\hline
\end{tabular}

\begin{tabular}{|l|l|l|l|l}
\hline 12a. DISTRIBUTION/AVAILABILITY STATEMENT & 12b. DISTRIBUTION CODE
\end{tabular}

Unclassified - Unlimited

Subject Category: 03

Available electronically at http://gltrs.grc.nasa.gov

This publication is available from the NASA Center for AeroSpace Information, 301-621-0390.

13. ABSTRACT (Maximum 200 words)

A parameter sensitivity study was conducted at the NASA Glenn Research Center's Icing Research Tunnel (IRT) using a 36 in. chord $(0.91 \mathrm{~m})$ NACA-0012 airfoil. The objective of this preliminary work was to investigate the feasibility of using ice shape feature changes to define requirements for the simulation and measurement of SLD icing conditions. It was desired to identify the minimum change (threshold) in a parameter value, which yielded an observable change in the ice shape. Liquid Water Content (LWC), drop size distribution (MVD), and tunnel static temperature were varied about a nominal value, and the effects of these parameter changes on the resulting ice shapes were documented. The resulting differences in ice shapes were compared on the basis of qualitative and quantitative criteria (e.g., mass, ice horn thickness, ice horn angle, icing limits, and iced area). This paper will provide a description of the experimental method, present selected experimental results, and conclude with an evaluation of these results, followed by a discussion of recommendations for future research.

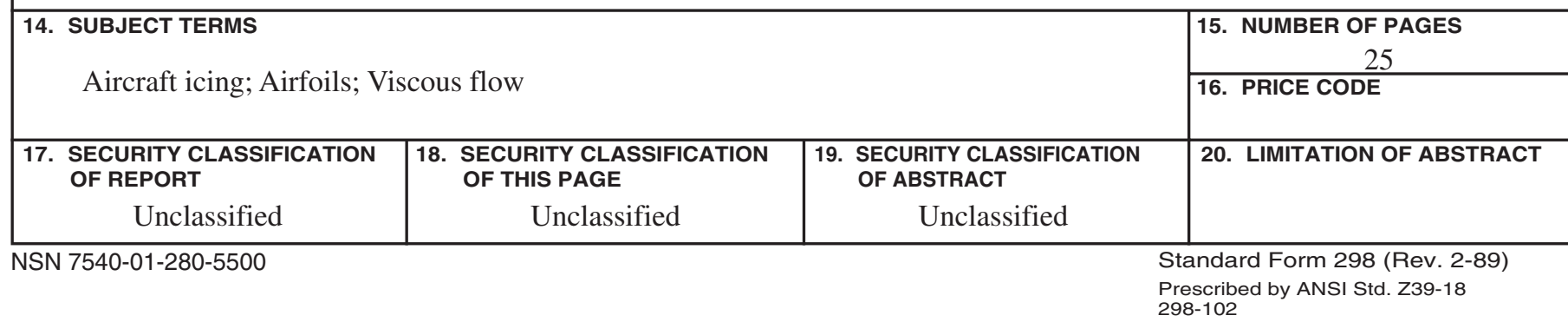



